\title{
IV The Circulation Processes of Latin American Literatures
}

\section{IV.1 Gabriel García Márquez: Worldwide Circulation and South-South Dynamics}

In order to be able to make further progress in answering the central question of the present study, namely "How is world literature made?" we need to focus now on the global connections among the circulation processes that constitute the conditions for a worldwide reception of Latin American writers.

On its way to becoming world literature, Gabriel García Márquez’s work would appear at first glance to have passed through the classic nodal points for (Latin American) literary circulation in the 1960s. ${ }^{102}$ Via Barcelona, Paris, and New York, it reached the centers within the former colonial empires, such as Bombay (now Mumbai) or Cape Town, where the privileged language of English had a canonizing function. If, in asking how world literature is made today, we are also concerned with the global differentiation with which the map of the world has, as we know, been redesigned, then the canonization processes at work for García Márquez will, precisely, allow us to ask: what does the oftproclaimed worldwide abandonment of the former logic of center and periphery mean for literary canonization processes? To what extent do the new literary circulation routes in the so-called Global South affect the denomination processes of world literature?

Thus, if we take a second look in order to focus more seriously on perspectives that take the concept of a Global South, on an epistemological level, into account, such as in the direction of Asia or of the Arabic world, a much more differentiated picture emerges on the level of South-South relationships. Aamir R. Mufti criticizes the fact that in current concepts of world literature, the problem of Orientalism has not been given enough attention (Mufti 2010: 458; cf. also Mufti 2018); although Mufti refers mostly to the 18th and 19th centuries, this problem is just as important in the context of the worldwide reception of García Márquez. In addition to the facts and figures of the book market, the issue here, on an intra-literary level, is also to what extent the aesthetic realm shows us concrete intertextual references between García Márquez and authors of the Global South, and to what extent we can distill from that the processes of

102 I also address the world-literary circulation processes of Gabriel García Márquez’s work in Müller (2018a, 2018b, 2018c).

Ә Open Access. ( 2021 Gesine Müller, published by De Gruyter. (c) BY-NC-ND This work is licensed under the Creative Commons Attribution-NonCommercial-NoDerivatives 4.0 International License. 
reception and transformation with respect to particular literary topoi, genres, or paradigms.

Let us take here, as illustrative of García Márquez's work, his central novel One Hundred Years of Solitude and its reception in the United States, India, and China, focusing as well on the Arabic world and Russia. In 1967, Cien años de soledad was published in Buenos Aires by Editorial Sudamericana with an unusually large first edition of 8000 copies, which was three times the norm; that same year, there were then even three more reprints, of 20,000 copies each (see Marling 2016: 25). As a result, García Márquez's earlier work was then also given more notice and republished in larger editions (Cohn 2012: 1). The main impetus for the international reception of the Boom in general and of García Márquez in particular, however, came from Spain, followed closely by France; Barcelona, where the author lived from 1968 to 1975 (see Shaw 2010), constituted a crucial node. $^{103,104}$

\section{IV.1.1 The United States as a Key Filter and Driver of Reception Processes}

Because García Márquez was a committed Communist and worked for Fidel Castro's Prensa Latina in Havana, Bogotá, and New York from 1959 to 1960, he was first met with suspicion, at the very least, in the United States. In his Conversations with Gabriel García Márquez, William Kennedy (2006: 61) gives a couple of reasons for the lack of interest, within the US, in Latin American culture and literature. First of all, there was a widespread tendency in the 1960s to reject socialist or communist systems outright. And on top of that, most of the US population considered Latin America at that time to be "worthless" because of its political and economic insignificance. This is the context in which the following commentary by García Márquez on the integration of Latin America into the (intellectual) map, made in 1967, should be understood:

103 This first and definitely decisive stage of international reception has been intensively studied over the course of the last decades and has developed into the stock theme of Latin American literature of the 1960s, which is why I do not examine it further here.

104 William Marling (2016) emphasizes how significant certain important people and particular life stages were for the world literary career of the Colombian Nobel Prize winner. Marling has mapped out which gatekeepers influenced García Márquez’s successes. To name just a few examples: García Márquez’s friend Plinio Apuleyo Mendoza; the writers' group in Baranquilla; Carlos Fuentes, as an older writer; an interview with Luis Harss; the literary agent Carmen Balcells; but also various governments and media conglomerates, as well as the cult surrounding the translator Gregory Rabassa. 
We're writing the first great novel of Latin American man. Fuentes is showing one side of the new Mexican bourgeoisie; Vargas Llosa, social aspects of Peru; Cortázar likewise, and so on. What's interesting to me is that we're writing several novels, but the outcome, I hope, will be a total vision of Latin America . . .. It's the first attempt to integrate this world.

(Castro 1967: vii)

If the Cuban Revolution represents Latin America's attempt to liberate itself from foreign control by the United States on a political level, the Boom represented the achievement of cultural autonomy, and with it the end of cultural colonialism in the literary and intellectual realm, in particular with respect to the US.

The attitude of the readership in the United States, which had ranged from uninterested to critical, changed abruptly in 1970 with the appearance of the English edition of Cien años de soledad, in a translation by Gregory Rabassa titled One Hundred Years of Solitude. The text was immediately voted one of the twelve best novels of the year by the editors of the New York Times Book Review. The paperback edition, published by Avon in 1971, then also began to circulate among the genuinely non-literary reading public (Johnson 1996: 133). For most North Americans, reading One Hundred Years of Solitude was their first contact with Latin American literature and therefore, at the same time, an introduction to that literature, which led to a perception of the novel as a microcosm of the entire "exotic" Latin American world. Because of the novel's success, much more Latin American literature was then published in the United States, and it was received by a much broader public (Shaw 2010: 27). In 1971, Ronald Christ who was also the first person to use the phrase magic realism (Marling 2016: 37 - was the editor of a special supplement to the magazine Review, which mostly included articles and reviews translated from Spanish into English but also incorporated reviews of Cien años de soledad from French- and Germanlanguage sources. García Márquez's soaring reception in the English-speaking world was then given a further boost by the first academic treatise written in English about his work: in 1977, the Frederick Ungar Publishing Company published George McMurray's Gabriel García Márquez, the first monograph dedicated to a Latin American, in its series on world literary figures such as Saul Bellow or Truman Capote. McMurray's book paved the way for a variety of English-language editions of essays and interviews, as well as other monographs. ${ }^{105}$ In Great Britain, on the other hand, it was not until 1990 that the Macmillan Modern Novelists series included a book by Michael Bell on

105 This includes the groundbreaking works of Bell-Villada (1990), Bloom (1989), Janes (1989), and McNerney (1989). 
García Márquez, also the first Latin American in that series. Donald Shaw calls the recognition of García Márquez's work by the English-language world of Hispanic studies the "consecration of Gabriel García Márquez as a world author" (2010: 33).

The above-mentioned exoticist understanding of Cien años de soledad, however, in which Macondo was a microcosm for "foreign" Latin America, is only one side of the coin of the reception in the United States. The other side involved the staging of archetypical universalisms and anthropological constants. The fact that there were multiple kinds of connectivity made it easy for reviewers and especially also literary scholars to weave the novel into a network of universalist world literature. Intertextuality research, in particular, identified countless allusions to the Bible, Faulkner, and Dostoevsky, among others (McGrady 1981, cited in Ortega Hernández 2007). This sort of interpretive line, leaning on Western literary traditions, is no small part of what contributed to the resounding success that Cien años de soledad found in the metropolises of the Western and North American worlds (Marling 2016: 38; see also Düsdieker 1997: 335).

In addition, García Márquez’s narrative style, often characterized as "premodern" or "fairytale-like," was credited with having a decisive impact on postmodern writing: he is supposed to have triggered a narrative turn and initiated the rediscovery of storytelling (Düsdieker 1997: 324). What is significant here is the turn away from the fragmented narration of modernity and a "reorientation toward a consciously anachronistic orality" (Rückbesinnung auf eine bewußt anachronistische Mündlichkeit, ibid.), which, in its fairytale-like character, stands in opposition to the nouveau roman and to the temporal regimen of modernity. In this view, Thomas Pynchon and Toni Morrison (most markedly in her 1987 novel Beloved), for example, are considered to be carrying on the narrative tradition of Marquez's poetics.

It was precisely the matter-of-fact way in which the characters' antirational and mythical understanding of reality was presented in Cien años de soledad that made Macondo into a model not only for all of Latin American literature but also for broad swaths of US literature. There are actually disparate and paradoxical currents combined within García Márquez's art that functioned as points of reference for writers in the United States after 1970: the mixing of literature and anthropological knowledge, of facts and fiction, of the trivial and the extraordinary. An example of this dimension of reality is the pastor in Cien años de soledad, who speaks of nothing but the arrival of the Antichrist - who then, in that fictional world, actually appears (see Düsdieker 1997: 323, 324, 353). In terms of its contents, then, García Márquez's novel provides literary material that can be picked up and used by (ethnically, religiously, etc.) marginalized 
groups on potential peripheries in order to undermine the "discourses of domination, knowledge, and history" (Herrschafts-, Wissens- und Geschichtsdiskurse, Düsdieker 1997: 336) that have been established by the literary and political centers. Through its own English-language canonization of Gabriel García Márquez's work, the United States became the primary driver of the reception of that work for the English-speaking Global South, to which we now turn our attention.

\section{IV.1.2 Reception in India}

In India, the first reception of Cien años de soledad took place in English. The first translations into regional Indian languages followed the enormous surge in popularity and reputation that García Márquez enjoyed after he was awarded the Nobel Prize in 1982; these translations were undertaken from English into Hindi, Bengali, Marathi, Malayalam, and Tamil (Maurya 2015: 252). ${ }^{106}$ Indradeep Bhattacharyya (2014) describes the astonishing increase in sales of Gabriel García Márquez's books after his death in 2014: his works were on display in all of Kolkata's major bookstores - Kolkata also being the site of the world's largest annual public book fair - and were soon sold out. ${ }^{107}$ Bhattacharyya also draws parallels with the developments in the Indian book market after the Nobel Prize award in 1982. ${ }^{108}$ As he tells it, the reception of García Márquez in India appears to be characterized by two sudden upswings, one following the Nobel Prize and one following the author's death. But the cautious story of García Márquez's reception in India already began in the early 1970s, in Bhattacharyya's account:

Way back in 1971, when Manabendra Bandyopadhyay introduced him in the comparative literature syllabus at Jadavpur University, nobody had heard of the author, but he noticed an instant liking among students for One Hundred Years of Solitude. "The first sign was

106 The four-volume Bibliographic Guide to Gabriel García Márquez (ed. Nelly Sfeir de González) includes the following translations for the years from 1949 to 2002: Malayalam: Cien años de soledad (tr. Kottayam, India: Di. Si. Buks, 1995), El amor en los tiempos del cólera (Vi ke Unnikrsnan, tr. Kottayam, India: Di. Si. Buks, 1997, 1998); Gujarati: La Mala hora (Nirañjana Taripathi, tr. Amadavada, India: Gurjara Grantharatna Karylaya, 1991).

107 See Bhattacharyya (2014): "Ranjit Adhikary, sales manager of Supernova Publishers, Penguin's exclusive distributor in eastern India, said: 'The demand for Garcia Marquez's books has shot up exponentially. Every day we receive orders for at least 90-100 copies of each title. The two books most in demand - One Hundred Years of Solitude and Love in the Time of Cholera - are out of stock. They will be back in circulation next week.'”

108 "College Street bookseller Suvojit Saha said, 'Demand for Garcia Marquez's books had shot up in 1982. It has again peaked after his death. We are sending away customers as there is no supply. We had about 30 titles; we sold out last Saturday"” (Bhattacharyya 2014). 
that students read the text themselves, which was definitely not the case with someone like Joyce,” Bandyopadhyay said.

One key to Gabriel García Márquez’s success in India, then, can be found in a certain literarily staged familiarity and the associated "readability" that appeals to every reader, regardless of their level of education or cultural background, with its orality and fairytale-like character.

\section{Magical Realism as an Intensifier of Reception}

El realismo magical [sic], "magic realism," at least as practiced by Garcia Marquez, is a development of Surrealism that expresses a genuinely "Third World" consciousness. It deals with what Naipaul has called "half-made" societies, in which the impossibly old struggles against the appallingly new, in which public corruptions and private anguishes are more garish and extreme than they ever get in the so-called "North," where centuries of wealth and power have formed thick layers over the surface of what's really going on.

(Rushdie 1982)

As this quotation from Salman Rushdie makes clear, the global establishment of magical realism on the basis of the shared experiences of a Global South is of critical importance for the reception of Gabriel García Márquez in Indian literature. Magical realism, as an aesthetic form, became the mantra of what was then called the Third World, immediately applicable as it was to other marginalized and socially segregated places, forms, and spaces - the reception of the later India Boom was also influenced by it. Mariano Siskind's (2012) study leads the way in examining the worldwide diffusion of magical realism as a postcolonial form of expression, giving Gabriel García Márquez and the "globalization of One Hundred Years of Solitude," ${ }^{109}$ or to be more specific the material and concrete process of the global circulation of the novel, a central role in this development (867, note 80). For "Macondo is the mediation between the idiosyncratic hyper-localism of the Colombian tropical forest and the general situation of the continent. Macondo is the village-signifier that names the difference of Latin America, and later, perhaps of the Third World at large" (854). Siskind describes the magical perspective, with respect to a specific subaltern sociocultural experience of colonialism and of other forms of local or global oppression, as a particular intraliterary characteristic of the

109 Worldwide, the number of writers in postcolonial situations whose work was significantly influenced by García Márquez’s novel One Hundred Years of Solitude is large. In addition to Salman Rushdie and Toni Morrison, who have already been mentioned, we should also list Latife Tekin (Dear Shameless Death, 1983), Ben Okri (The Famished Road, 1991), Mia Couto (Sleepwalking Land, 1992) and Mo Yan, whom I will discuss in more detail later (cf. Siskind 2012: 857-58). 
postcolonial variation of magical realism, which began with One Hundred Years of Solitude: "the narrative and interpretative horizon opened up by García Márquez by rendering visible the relation between the universality of (colonial, postcolonial, capitalistic) modern history, and the particularity of local forms of oppression" (2012: 855).

In other words, it is the universalistic dimension of magical realism in the context of the Global South that Indian readers find so fascinating in the texts of the Colombian writer, paired with the specific entanglement of reality and fiction, as the García Márquez translator Buddhadeb Bhattacharjee explains: "Take The Autumn of the Patriarch, for instance. The sweep of the novel startled me. At that time, Latin America had seven-eight military dictators who exercised ruthless power. It could be the story of any of them - their despotic rule as well as their helplessness" (Bhattacharyya 2014).

The success of Salman Rushdie's Midnight's Children (1981) is another factor not to be dismissed in García Márquez's success in India. In numerous reviews and interviews, Rushdie himself professes his admiration for his Latin American colleague; for example, in retrospect, he emphasizes the enormous impression that reading One Hundred Years of Solitude made on him and the feeling of familiarity that he experienced with it:

And of course when I did read it, I had the experience that many people had described of being forever lost in that great novel. Unforgettable. I think all of us can remember the day when we first read Gabriel García Márquez; it was a colossal event. One thing that struck me, . . . was the incredible similarity between the world he was describing and the world that I knew from South Asia, from India and Pakistan. It was a world in which religion and superstition dominated people's lives; also a world in which there was a powerful and complicated history of colonialism; also a world in which there were colossal differences between the very poor and the very rich, and not much in between; also a world bedeviled by dictators and corruption. And so to me, what was called "fantastic" seemed completely naturalistic.

(Rushdie 2007, cited in Siskind 2012: 860-61)

In scholarly circles, as well, we can observe that the reception of Gabriel García Márquez in India picked up speed after the publication of Rushdie's Midnight's Children and the awarding of the Nobel Prize to García Márquez. In Hyderabad, for instance, the first "International Seminar on García Márquez and Latin America” took place in $1984 .{ }^{110}$ Then, beginning in the 1990 s, a broad

110 A selected collection of the lectures can be found in Bhalla (1987). Analogously to the developments after the Nobel Prize in 1982, after García Márquez's death the English and Foreign Languages University in Hyderabad organized a further seminar on his work, on March 25, 2015, entitled “Márquez and Literatures of India.” The program can be viewed online at http:// efluniversity.ac.in/images/Documents/schedule.pdf. 
field of research into postcolonial fiction and magical realism opened up, within which García Márquez, along with Rushdie and some others - and particularly García Márquez's influence on Indian literature - played a prominent role. ${ }^{111}$

\section{Gabriel García Márquez’s Influences on Indian Culture}

In Indian literature, or at least in its internationally circulating literature, the traces of García Márquez's literary aesthetic are truly remarkable. The connections between the works of García Márquez and Salman Rushdie, already mentioned above - especially in terms of magical realism - are well-known and have been intensively studied all around the world. Thus, for example, Deep Basu writes:

And not to forget Salman Rushdie, whose first epoch making novel Midnight's Children and controversial novel Satanic Verses were heavily influenced by Marquez's Magic Realism. Rushdie once told in an interview that there was "a whole group of writers" including himself who, "broadly speaking, are thought of as a family," namely a Magical Realism family.

(Basu nd)

Amitav Ghosh (The Circle of Reason, 1986) and Arundhati Roy (The God of Small Things, 1987) are also a part of this group. Comparisons between Roy's novel and García Márquez are as common as they are a part of the commercialization of Roy's work. Responding in an interview to a question about his literary models, Ghosh, for his part, names García Márquez as the most important source of inspiration for his work (Aldama 2002: 87).

But even beyond literature, in the narrower sense, the influence that García Márquez has had on Indian culture has been enormous - on the movie screen, for instance, it opens up possibilities of having recourse to an oral and magical tradition in order to draw critical attention to colonialism, imperialism, and their effects. Here Deep Basu, again:

111 More recently, Christopher Warnes (2009) and Taner Can (2015) have also written about magical realism in the English-language postcolonial novels. Both of them extend an invitation to take a new look at magical realism, which they consider to be central to English-language postcolonial fiction, for example in the work of Salman Rushdie, Shashi Tharoor, Ben Okri, and Sly Cheney-Coker. On the question of the relations between Latin America and India, in particular, Susanne Klengel and Alexandra Ortiz Wallner have recently developed a new paradigm, which uses the label Sur/South to provide an alternative to the concept of the Global South, and which brings up the question of new Orientalisms (see Klengel and Ortiz Wallner 2016). 
Lijo Jose Pelliserry's film Amen has been described as the most successful experiment with magic realism in Malayalam cinema. He says that though India and Colombia exist in two different hemispheres, the sensibilities are almost the same. Indians also have uncountable legends and supernatural stories and lores borne out of fertile imagination, robust beliefs, large families and a culture of strong family and community bonds. (Basu nd)

In summary, the reception of García Márquez in India can be characterized as having gone through several stages. What prepared the ground was surely the slow dissemination of magical realism on a global level, advanced by the awarding of the Nobel Prize to Miguel Asturias in 1967, the year in which Cien años de soledad was published. When the novel was translated into English in 1970, worldwide success swiftly followed, and in 1971 it was already on the syllabus in India's comparative literature programs. As of the 1980s, the significant influence of Gabriel García Márquez’s work on Rushdie and other "postcolonial" writers could be clearly seen. When García Márquez was awarded the 1982 Nobel Prize in Literature, that acted as a further catalyst for these developments, strengthening scholarly interest in García Márquez's work from a postcolonial perspective, which is linked with magical realism. This tradition lives on in countless Indian fiction writers who also have international visibility (beginning with Ghosh and Roy). And finally, when García Márquez died, in 2014, the interest in his work and the allusions made to it by Indian writers grew very intense once more.

\section{IV.1.3 Reception in China}

Gisèle Sapiro (2016: 84) writes that in countries in which the economic realm is subordinated to the political realm, and the institutions that determine cultural production and the organization of the intellectual professions are run by the state, such as in Fascist or Communist countries, the production and circulation of symbolic goods is highly politicized. This could be the headline for the reception of García Márquez in China.

\section{Literary Boom in the 1980s: García Márquez as Figurehead}

In the early 1980s, in the aftermath of the painful cultural revolution, the newly crowned Nobel Prize winner García Márquez became a literary and cultural figurehead for the "New China." The background context for this can be outlined very quickly: the 1980s marked an unusually successful and productive phase for literature in China, after the most important writers of 20th-century world literature had been translated and made accessible in China in the 1970s: 
writers like Franz Kafka, James Joyce, William Faulkner, Ernest Hemingway, Kawabata Yasunari, Mario Vargas Llosa, and also Gabriel García Márquez, who had not fit, prior to that, into the framework of a model socialist literature. García Márquez’s literature, in particular, gave great support to intellectuals. As one Chinese critic noted, "It was as though a pal from your own village had become a millionaire” (Es como si un compadre del mismo pueblo se hubiera convertido en millionario; Ye 2015: 29), because in China García Márquez was still considered a "third-world artist."

The Nobel Prize also marked the beginning of the major reappraisal of García Márquez's oeuvre in the Chinese literary marketplace: in 1982, Yiwen Chubanshe (Translation Publishers of Shanghai) published an anthology of his works from 1950 to 1981, and in 1987 two different versions of El amor en los tiempos del cólera were published, as well as the famous poetological interview El olor de la guayaba (The smell of the guava), with Plinio Apuleyo Mendoza (Ye 2015: 29). In 1983-84, interestingly, there was at the same time an official campaign directed against magical realism because of its anti-socialist "mind pollution.” Because of that, China had to wait until 1994 for a complete translation of Cien años de soledad. And it was not until 2011 that the first authorized edition appeared on the market. ${ }^{112}$ There were indeed two editions of the novel published as early as 1984 - one based on the Spanish original, and the other translated from the English (Ji 2015: 358) - but both of them were drastically shortened, as the novel had been criticized as being obscene and representing superstition (see Ye 2015: 29).

The 1980s was also when China's Xungen literary movement was formed, which looked to the roots of Chinese civilization and strove for an artistic style that would harmoniously combine tradition and modernity. Han Shaogong, one of the main protagonists of the Xungen movement, noted in 1985 that: "Literature has its roots. Literature has to be deeply rooted in the ground of the people's traditional culture. If not, the Tree of Literature will never bloom" (Han 1985: 2, cited in Ye 2015: 30). Chinese writers found points of connection in García Márquez's poetics, and a real enthusiasm for Latin American culture broke out (Gálik 2000: 161). But entirely new translation strategies had to be developed, because there was no established literary movement in China that could be compared with magical realism (Ji 2015: 358).

112 All previous editions of Cien años de soledad in China had appeared without the official permission of the author. Chen Mingjun, the head of the publisher Thinkingdom House, finally acquired the rights for a million dollars (see Flood 2011). 


\section{Mo Yan and Magical Realism in China}

Mo Yan (b. 1955) is the most internationally recognized of the Xungen writers, and he won the Nobel Prize in Literature in 2012. His 1986 story cycle 红高粱家族, Hóng gāoliang jiāzú (Red Sorghum), very closely follows García Márquez’s magical realism narrative style. And in his 1996 novel 丰乳肥慰, Fēng rǔ féi tún (Big Breasts \& Wide Hips), he not only deals with the obsessions of the protagonist that give the book its title, but also rewrites China's extremely varied 20th-century history. With a sharp eye for the peculiar, he deconstructs the official historiography of the Chinese revolutionary age (see Siskind 2012: 857). The events are reflected in Yan's Chinese counterpart to Macondo, the provincial universe of his fictionalized birth city, Gaomi, in the province of Shandong. The author confesses in an interview, "I was born here, I grew up here, my roots are here" (Ye 2015: 30). Thus, it is no coincidence that Mo Yan was recognized by the Nobel Prize committee for his "hallucinatory realism" (Flood 2012), which can be seen as an adaptation of the 20th-century Latin American poetics of magical realism. García Márquez's influence on Yan's writing can also be seen in the fact that the theme of center and periphery always enters into Yan's narratives.

Mo Yan once commented that his experience of famines during his childhood constituted a formative learning process for him, which he calls "thinking about life through my stomach and knowing the world through my teeth" (pensar la vida con el estómago y conocer el mundo con los dientes; Ye 2015: 30). The literary embodiment of such experiences of privation is similar in the work of Yan and of García Márquez, an embodiment that can be understood as the expression of a specific literary aesthetic of the Global South. This can be seen, for example, in literary stagings of the consumption of inedible things. In Yan's story "Iron Child," for example, because there is nothing to eat, the protagonist eats steel rods; in Cien años de soledad, meanwhile, unrequited love turns Rebeca into a geophagist, an earth eater. Fan Ye interprets this behavior as a transcultural posture of dissent and a silent protest by the marginalized against their oppressors (31-32).

In one of his "Confessions," Mo Yan records the poetological and ideological influence that García Márquez and Faulkner had on him (37), in the process, interestingly, categorizing García Márquez as a Western writer:

In the year 1985 I wrote five novellettes and more than ten short stories. There is no doubt that where their world view and artistic devices are concerned, they were strongly influenced by foreign literature. Among Western works the greatest impact came from García Márquez's One Hundred Years of Solitude and William Faulkner's Sound and Fury.

(Gálik 2000: 161) 


\section{IV.1.4 Remapping World Literature?}

Of course there are other regions of the world and other cultural contexts in which aspects of the enormous global impact of García Márquez's literature can be examined and developed, for example Japan, South Africa, or Russia, where 2012 was declared the Year of García Márquez, in honor of his 85th birthday, and celebrated with a large variety of cultural events: for instance, seven metro cars, decorated with a larger-than-life portrait of the author and quotations from his writings, were driven around Moscow. The reception in the Arabic world, where Cien años de soledad was translated into Arabic from the French version in 1979, is also interesting. As with India and China, the two areas of the Global South that we have discussed, there are also a whole series of social, economic, and political problems that are shared between many Arab and Latin American countries and that encourage similar reading patterns and expectations. This is the basis for the cross-fertilization between local literary traditions turned postcolonial and globally spreading magical realism - especially in the form of Cien años de soledad - which enables the reproduction of political and cultural fractures and disruptions using the means of orality and the fairytale form. As a spotlight on the contemporary literature of the Arab world in this context, we can turn to Les 1001 années de la nostalgie (1001 years of nostalgia), by the Algerian Rashid Boudjedra, ${ }^{113}$ a book that not only alludes, in its title, to One Hundred Years of Solitude as well as A Thousand and One Nights, but also adopts narrative structures from both of those works (see Jarrar 2008: 307; Rabia 1981: 96).

Gabriel García Márquez is without a doubt a world literary figure, one who finds the same kind of enthusiastic response in both the Global North and the Global South. If we look at the various reception filters, taken together, we can identify two intra-literary tendencies. First, for a successful reception in the Western world in the 1970s and 1980s, it was essential for a work to be able to be woven into a net of universalistic world literature that had been canonized in the West and, at the same time, for it to be Orientalist. Secondly, in the countries that stand here for a Global South, a specific shared experience and aesthetic related to the postcolonial situation also appears to be of importance. These two reception filters are also on display in the often-used explanation of the success of Cien años de soledad that what makes it convincing everywhere in the world is its unique combination of connectedness to the universal

113 Published 1979 by Denoël (Paris). In 1981, the novel was also published in Arabic (entitled Alf wa' am min al-hanin). 
dimensions of modern history with the particularity of local forms of oppression (Siskind 2012: 855).

It is the combination of these aspects that provides an important indication as to why García Márquez remains predestined, to this day, to be the only writer from the Global South to appear in Western rankings of world literature (see Trojanow 2017). The reception of García Márquez as a now-irrevocable part of the Western canon of world literature can be understood as the reassurance that space has been made for the thoughts and memories of marginalized voices, without having to leave the framework of established Western thinking. This is the context in which we should understand Mo Yan's matter-of-fact categorization of García Márquez as a Western writer.

If we look at the canonization history of García Márquez as a worldrenowned author, we can say that, in spite of a global differentiation, there is nevertheless a series of stages to be moved through, and one has to go past Barcelona, Paris, or New York to get to Mumbai, Beijing, and Casablanca. The denominating centers of the West and North continue to wield an enormous amount of power. This finding is also confirmed by the fact that the worldwide reception of García Márquez's work intensified following the two significant moments of his Nobel Prize award and his death.

But it also becomes clear that a South-South perspective has heuristic potential, which is nourished by the question of the possible existence of decidedly "Southern" aesthetics and forms of representation. This seems to be even more significant when we look at the literary modeling of shared historical experiences within the Global South, experiences that reach from colonial history through integration into the economic, social, and cultural transformation processes of global modernity. ${ }^{114}$

114 This perspective brings up the question of whether Gabriel García Márquez could not also serve as an example of how cultural products contribute to the creation and recreation of narratives of the global, thereby reaching a transnational readership. Compare Héctor Hoyos's reading of Borges and Bolaño (Hoyos 2015: 4). 


\section{IV.2 Octavio Paz's Path to Recognition in World Literature: Network Building and International Reception}

If we ask ourselves what configurations made Octavio Paz, in turn, a worldrenowned author, we will of necessity have to look at his networks and his extra-literary commitments, which made him not only a literary figure on the world stage but also a key intellectual figure. In this volume, we have already looked at Octavio Paz's work from a different angle: for the publisher Siegfried Unseld, Paz's work matched up almost perfectly with the European-defined criteria that the Suhrkamp Verlag applied to world literature in the 1970s and 1980s. A comparable course of reception became visible on an international level in 1990, when Paz, at the age of 76 and after a long literary and intellectual career, was awarded the Nobel Prize in Literature. In the European media, this honor "was met with unanimous approval, thus making the image of the typical 'candidate' for the prize visible" (eine einstimmige positive Kritik erntete und damit das Bild des typischen "Anwärters" auf den Preis sichtbar machte; Bazié 1999: 83). ${ }^{115}$ In the following, I will first take a detour into the translation statistics in order to illustrate some of the characteristics of Octavio Paz's international canonization, and then go on to show how decisive, in his case, his extra-literary activities were for his rise to worldwide literary fame. Of course, those extra-literary factors only worked in combination with the intra-literary ones. Octavio Paz, more than almost any other Latin American writer, is an absolute exemplar for these processes.

\section{IV.2.1 On the Translation Statistics}

Unlike with García Márquez, Paz's world literary career cannot be traced based on one or several outstanding works, which is why in Paz's case, we have put together overviews of the translation statistics for his entire oeuvre. ${ }^{116}$ His rise to

115 Bazié examines French, German, and British responses to the Nobel Prize in Literature award, taking into consideration the extent to which literary critics in each of their national contexts support the award of the Nobel Prize to writers who are already very well-known, a criterion that applied to no other Nobel prize winner in the period studied, 1984-1994, so perfectly as it did to Octavio Paz (Bazié 1999: 83).

116 This research into the translation statistics, carried out in 2016 and 2017, was based on UNESCO'S Index Translationum (see http://www.unesco.org/xtrans/) as well as a multitude of sources for each of the various languages. I am grateful to Katharina Einert, Vicente Bernaschina Schürmann, Elena Sandmann, and Maxi Hoops for their research on this data. 
Table 1: Translations before and after the Nobel Prize (through 2017).

\begin{tabular}{lrr}
\hline Language & $\begin{array}{l}\text { Number of Translations } \\
\text { (Up to 1990) }\end{array}$ & $\begin{array}{l}\text { Number of Translations } \\
\text { (1991 Onwards) }\end{array}$ \\
\hline French & 39 & 16 \\
English & 35 & 16 \\
Portuguese & 18 & 11 \\
German & 17 & 12 \\
Dutch & 12 & 5 \\
Swedish & 9 & 3 \\
Italian & 8 & 13 \\
Japanese & 7 & 15 \\
Turkish & 6 & 9 \\
Persian (Farsi) & 4 & 7 \\
Polish & 3 & 10 \\
Chinese & 0 & \\
\hline
\end{tabular}

the stature of world literary figure does appear, at first, to have taken a classic path, in that it can be identified, in particular, through translations for the European and United States literary marketplace. This can be seen based on the languages into which Paz's work was translated, early and very often. The following tables provide a brief overview of the translation statistics in order to roughly trace this path. The first table shows the number of translated monographs before and after the 1990 award of the Nobel Prize to Paz, ranked by the languages into which his work had been most translated before 1990 .

Table 2: Total Number of Translations, by Language.

\begin{tabular}{lr}
\hline Language & Number of Translations \\
\hline French & 55 \\
English & 51 \\
German & 29 \\
Portuguese & 29 \\
Japanese & 22 \\
Italian & 21 \\
Dutch & 17 \\
Turkish & 15 \\
Persian (Farsi) & 14 \\
Swedish & 12 \\
Chinese & 10 \\
Polish & 10 \\
\hline
\end{tabular}


Aside from a few individual texts, Paz's work was first published in France, in the US/UK, in Brazil/Portugal, and in Germany before being translated into the languages of regions that were considered less decisive for the institutions of an international literary canonization in the second half of the twentieth century - such languages as Japanese, Turkish, Polish, and Chinese. When we look at the total number of translations (Table 2), therefore, those languages into which there had been relatively few translations before the Nobel Prize award and then more translations afterwards move higher up on the list, an effect that can be observed, for instance, in the Japanese market.

And what, then, is the relationship between these observations and the chronological sequence of the first translations into each of the respective languages? If we compare the year of publication of the first translations in various linguistic regions (Table 3), we will notice that Paz was translated into a large number of different languages very early; for example, he was already translated into Swedish in the early 1960s.

Table 3: Year of the First Translation into Each Language.

\begin{tabular}{lll}
\hline Year & Language & Original Title \\
\hline 1957 & French & ¿Águila o sol? \\
1960 & Swedish & La estación violenta \\
1961 & English & El laberinto de la soledad \\
1961 & Italian & El laberinto de la soledad \\
1963 & Turkish & Piedra de sol \\
1970 & German & El laberinto de la soledad \\
1972 & Portuguese & Constelação \\
1974 & Dutch & Piedra de sol / ¿Águila o sol? \\
1977 & Japanese & El mono gramático \\
1981 & Polish & Poezje wybrane [poetry volume \\
& & collected especially for the translation] \\
\hline
\end{tabular}

Here it can be seen that in some linguistic areas the reception began relatively late but then intensified rather quickly, for example with Dutch and with Japanese, whereas for other languages, there were early translation efforts but they did not lead to a particularly large number of translations over the years. What meaning do these pronounced reception tendencies have, beyond mere statistics, in the context of Paz's career as a writer on the world literary stage? 


\section{IV.2.2 Writer-Diplomat-Scholar}

Octavio Paz provides an exemplary case for showing how it was above all his extra-literary activities that helped him achieve international literary success. Some of the important components of that engagement included his ambassadorship in India, guest professorships (especially in the United States), and magazines that he founded.

Paz's international reception began in 1936, shortly after the outbreak of the Spanish Civil War, when he wrote the poem "No pasarán" in support of the Republicans (Volpi 2008: 13). This poem brought Paz attention around the world, and thanks to Pablo Neruda, who had read Paz's poetry collection Raíz del hombre (The root of man; 1937), Paz was invited to the anti-Fascist Second International Congress of Writers for the Defense of Culture (II Congreso Internacional de Escritores Antifascistas) in Valencia in 1937 (Volpi Escalante 2008: 15). After he came back from Europe, Paz founded the magazine Taller (Workshop; 1938-1941) along with Rafael Solana, Efraín Huerta, and Âlvaro Quintero Álvarez. This magazine provided a forum not only for the poetry of Paz's generation but also for the Republican poets from Spain who had been granted asylum in Mexico under President Lázaro Cárdenas (1934-1940; Perales Contreras 2013: 41). This was the beginning of the literary and intellectual network between Latin America and Europe that Octavio Paz created. Among the Spanish writers published in the magazine were Manuel Altolaguirre, Ramón Gaya, Juan Gil-Albert, Emilio Pradós, Antonio Sánchez Budo, Luis Cernuda, Federico García Lorca, José Bergamín, and María Zambrano (Perales Contreras 2013: 42).

This network continued to grow when Octavio Paz spent a year in the United States on a Guggenheim Fellowship and then entered Mexico's Foreign Service and in 1945 was sent to Paris. During this time, Paz met Pablo Picasso, the surrealist poets Louis Aragon and Paul Éluard, the sociologist Raymond Aron, and also François Bondy, publisher of the liberal magazine Preuves (Proofs), in which some of Paz's texts were later to appear (Perales Contreras 2013: 57). During Paz's time in Paris, he also published some poems in the magazine Fontaine (Fountain; Perales Contreras 2013: 58). Fabienne Bradu and Philippe Ollé-Laprune add to this list more writers and intellectuals whom Octavio Paz met in those years and who later became friends as well as disseminators and translators of his work: Henri Michaux, Jules Supervielle, Georges Schéhadé, Jean Cassou, Raymond Queneau, Roger Caillois, Julien Gracq, Cornelius Castoriadis, Emil Cioran, and his first translators into French: Guy Lévis-Mano, Jean-Clarence Lambert, Carmen Figueroa, and André Pieyre de Mandiargues (Bradu and Ollé-Laprune 2014: 156). Paz also met other Latin American writers in Paris, however: Alejo Carpentier, Gabriela Mistral, José Bianco, Adolfo Bioy Casares, 
Blanca Varela, Luis Cardoza y Aragón, and also the painter Fernando Szyszlo. Paz would end up remaining friends with and connected to some of these people for a long time (Perales Contreras 2013: 59). In the context of the UNESCO publication of an Antología de la poesía mexicana (Anthology of Mexican poetry), Paz met Samuel Beckett and helped him to translate the anthology into French; there was also an edition in English (Perales Contreras 2013: 60; Domínguez Michael 2014: 605).

After a few months in India, Japan, and Switzerland, Octavio Paz returned to Mexico in the fall of 1953. Thanks to the friendship that he had made with José Bianco while he was in France, Paz also began to work on the Argentine magazine Sur (South) during this time, one of Latin America's most important literary magazines (Perales Contreras 2013: 65). In 1962, he was named Mexico’s ambassador to India, and he also became increasingly prolific in his writing. During these years he also collaborated on the magazine Mundo Nuevo (New world), which was published in France and headed by Emir Rodríguez Monegal.

In response to the Tlatelolco massacre in 1968, Paz resigned his ambassadorship. He traveled to Barcelona, then to France, and finally to the United States. There he was first in Pittsburgh, where he gave a lecture on Latin American literature. After that, he gave the Hackett Memorial Lecture in Austin, Texas, on October 30, 1969. In that lecture, he emphasized how absolutely he had distanced himself from the Mexican government and, as a result, that his role was now that of an intellectual who was independent of the state. Three months later, he taught literature in Austin and participated in the local poetry festival, along with Robert Duncan and Robert Creely. Shortly after he returned to Mexico in 1971, he went to England, where, on the recommendation of his friend George Steiner, he was named to the Simon Bolivar Chair in HispanoAmerican Literature at Cambridge University (Perales Contreras 2013: 111). Back in Mexico, Octavio Paz founded an independent cultural magazine, Plural. The development of this magazine increased and consolidated Paz's international stature and the extent of his networks.

\section{IV.2.3 First Phase of Reception: France}

In terms of Paz's reception in France, the dominant interpretations of his work in the 1950s saw him as the representative of a reformulated surrealism. Particularly in France, this kind of interpretation took as a reference point what was proper to oneself, going from there to demonstrate an openness to the new.

The first poems and essays of Paz's to circulate in French appeared between 1946 and 1956 (Bradu and Ollé-Laprune 2014: 156-57). The first translation of a 
complete volume of poetry to appear in France was Aigle ou soleil? (1957; Eagle or Sun?; original Spanish title ¿Águila o sol?). Over the next 13 years, publications of Paz texts in French included "Soleil sans âge" (in Le Surréalisme, Même, Nr. 5, 1959); Le Labyrinthe de la solitude (1959); L'Arc et la lyre (1965); Liberté sur parole (1966); Marcel Duchamp, ou le Château de la pureté (Geneva, 1967); Deux transparents: Marcel Duchamp et Claude Lévi-Strauss (1970); and Versant Est, et autres poèmes, 1957-1968 (1970), as well as other essays and poems that appeared in a variety of magazines (Bradu and Ollé-Laprune 2014: 157-60). After those first 13 years, his work in France had proven to be not only a further development of surrealism but also a critical examination of it.

Claude Esteban's foreword to Versant est, "De la poésie comme insurrection" (On poetry as insurrection), is an important reference. In it, he shows how Paz's poetry and poetics became established in France in the 1960s (Bradu and Ollé-Laprune 2014: 87-101) and points out two important changes in their reception: a distancing from surrealism, and a reading of the poems in the context of the metapoetic and critical ideas presented in Paz's prose work. Thus, while Esteban does note similarities to surrealism in Paz's poetry, he also explains the point at which Paz distanced himself from André Breton and his group (Bradu and Ollé-Laprune 2014: 89). This distance, this “disagreement” (desacuerdo) with surrealism is documented using theoretical, metapoetic, and poetological observations from El arco y la lira (The Bow and the Lyre). It is interesting to note that from that moment forward, Octavio Paz's essayistic and critical work came more to the fore in his French reception than did his poetry.

We can see a parallel to this in Sweden: that was where, in 1960, after the first volume of poetry that appeared in French, the second translation anywhere in the world of a work by Paz into another language appeared. The translator of the volume, Den våldsamma årstiden (The violent season; original Spanish title La estación violenta), was the poet and travel writer Artur Lundkvist, who was also later well-known on the international literary scene because he was considered an influential member of the Swedish Academy; he belonged to the Nobel Committee for Literature from 1969 to 1986. Beginning with this poetry translation, with which Lundkvist, who was particularly interested in Spanish-language literatures, introduced Paz to the Swedish public at a very early point in time, we can observe a development that is comparable to that in France: in Sweden, there was an early interest in Paz's poetry and his version of surrealism that then, however, subsided around the same time as it did in France, when interest in Paz was transferred more towards his essayistic work; in Sweden, however, there were many fewer Paz translations overall than there were in France. The two poets Artur Lundkvist and Lasse Söderberg, who translated Paz's poems and essays in the 1960s and 1970s, underscore the particular 
development that surrealism underwent in Paz's poetry. Lasse Söderberg explains that his motivation for translating Paz was above all a poetic one, which developed after doing some of his own reading in France and after meeting Paz in person (Zetterlund 2016: 176).

\section{IV.2.4 Second Phase of Reception: The United States}

Octavio Paz repeatedly testified to the importance of his numerous stays in the United States for his career as well as for his positive connection with the neighbors to the north. During his years in Cambridge and at Harvard, Julio Scherer, the head of the newspaper Excélsior, also invited him to found the cultural magazine Plural, for which he drew on his international contacts:

His collection of national and foreign collaborators was exceptional, to begin with, because it included the broad network of contacts that Paz had woven together over two decades. Residing at Harvard for long periods, Paz sent contributions from the friends that he made or met again to the offices of Plural in Mexico. During that period, the magazine published pieces by the Americans Bellow, Howe, Bell, Galbraith, Chomsky, and Sontag; the Europeans Grass, Eco, Lévi-Strauss, Jakobson, Michaux, Cioran, Barthes, and Aron; the Spaniards Gimferrer and Goytisolo; the Eastern Europeans Miłosz, Kołakowski, and Brodsky; and the Latin Americans Borges, Bianco, Vargas Llosa, and Cortázar. ${ }^{117}$

(Krauze 2014: 175)

In his book on Paz's network of contacts, Octavio Paz y su círculo intelectual (2013; Octavio Paz and his intellectual circle), Jaime Perales Contreras describes this phase and these networks in detail. In his description, it becomes clear how important the ramifications of his work with Plural were for Paz, because it connected him not only with very influential people in highly diverse fields of knowledge in the United States, but also with the scholarly debates and central innovative achievements of his time.

While Plural ensured widespread recognition for Octavio Paz as a poet and intellectual in Mexico and Latin America, it also allowed him to cement his position in the United States. Among the essay collections of his that were published in English in the 1970s, especially noteworthy are The Bow and the Lyre

117 "Su cuerpo de colaboradores nacionales y extranjeros era, de entrada, excepcional, porque recogía la amplia red de contactos que Paz había tejido a través de dos décadas. Avecindado por largos períodos en Harvard, Paz enviaba a las oficinas de Plural en México las colaboraciones de los amigos que reencontraba o hacía. En esa época publicaron los americanos Bellow, Howe, Bell, Galbraith, Chomsky, Sontag; los europeos Grass, Eco, Lévi-Strauss, Jakobson, Michaux, Cioran, Barthes, Aron; los españoles Gimferrer y Goytisolo; los europeos del Este Milosz, Kolakowski, Brodsky; los latinoamericanos Borges, Bianco, Vargas Llosa, Cortázar.” 
(Austin: University of Texas Press, 1973, with multiple printings in 1975, 1983, and 1991); Alternating Current (New York: Viking, 1973, second printing 1974; and further editions with other publishers: London: Wildwood, 1974; New York: Seaver Books, 1983; New York: Arcade Publishing, 1990); and Children of the Mire (Harvard University Press 1974, second printing 1975). In these texts, we see the development of Octavio Paz's political, poetic, and cultural ideas on modernity, a subject that would turn out to be central to the reception of his work in the United States but also in Europe. In Jürgen Habermas's essay "Modernity - An Incomplete Project" (original 1981 German title "Die Moderne - ein unvollendetes Projekt”), for example, he quotes from several of Paz's articles. For a whole series of writers, Paz's ideas functioned as a diagnosis of the situation of modernity in the world, especially with respect to the development of Western modernity outside of Europe. ${ }^{118}$

In 1976, the magazine Plural ceased publication, and Paz founded a new magazine, Vuelta (Return/revival/revolution). Unlike Plural, Vuelta was not financed by a newspaper but rather by advertising and private backers. In this magazine, which was much more strongly shaped by Octavio Paz himself than Plural had been, he could develop his own position in a unique way. These years, during which Paz once again lived in Mexico, also show in what very different ways Octavio Paz's intellectual and political position has been interpreted. This also has to do with a process of change in Paz himself, which is not always easy to get an overall sense of. Sergio Roncagliolo writes that "in a certain sense, Paz went through a process that was the opposite of Neruda's, something like George Orwell . . . The experience of the Spanish Civil War left him feeling rootless and confronted him with the moral ambiguity of all political factions” (2011). Enrique Krauze writes that he met Octavio Paz in 1976, and that the Octavio Paz whom he met was no longer a revolutionary - or at least not the same poet who had supported the Spanish Republicans in the 1930s and the Mexican students in the 1960s. Or was he?

Or rather, I should say, he was, but in a different way: his critical passion . . . had turned against himself, not to negate the human aspiration to brotherhood, justice, equality, and liberty, but rather to cleanse it of the lie that dogmatic ideologies and totalitarian regimes had converted it into.

This search for objective truth implied a reevaluation of democratic liberalism. Undertaking such a search in Latin America was not a simple decision: it did not have the glorious aura of Marxism, nor did it promise utopia. It proposed a tolerant, clear-headed

118 For a relatively up-to-date interpretation of Octavio Paz's work along these lines from the United States, see Greiner (2001), especially chapter 4: “A Critique of Modernity” (77-108). 
coexistence among people, an active and alert citizenry, the harbinger not of an ideal society but of a civilized life. ${ }^{119}$

(Krauze 2014: 10)

Among leftists and students in Mexico, his ideas were met with rejection, but among liberal intellectuals in Latin America, Europe, and the United States, they were met with strong approval (Krauze 2014: 219). In the United States, in fact, Paz's literary, cultural, and political ideas were well received by liberal and conservative intellectuals both.

Without going further into the details of his reception in the United States and the awards he won there, we can say, overall, that the reception and dissemination of Octavio Paz's works in the United States in the 1970s and 1980s was fundamental to his development as a writer on the world literary stage. The translation of his poems into English was influenced by the interest of poets who were friends with him (including Charles Tomlinson, Eliot Weinberger, and Paul Blackburn). Paz's residencies at various universities in the United States, especially his visiting professorships at Harvard, gave him a scholarly authority that influenced the reception of his essays - published by such presses as Cornell University Press, the University of Texas Press, Viking, Grove, and Harvard University Press - around the world.

\section{IV.2.5 Examples of Global Reception: Asia}

Given that we are examining the degree to which Octavio Paz's literary success as a writer of world stature in Europe, Latin America, and the United States was promoted by his extra-literary activity and his networking, we should look here at two further places that, like France and the United States, became part of his biography and played a special role in his career: India and Japan. How was Paz received in each of these countries?

119 "Mejor dicho, sí lo era, pero de otro modo: su pasión crítica . . . se volvía contra sí misma, no para negar la aspiración humana a la fraternidad, la justicia, la igualdad y la libertad sino para depurarla de la mentira en que la habían convertido las ideologías dogmáticas y los regímenes totalitarios.

Esa búsqueda de la verdad objetiva implicaba una revaloración del liberalismo democrático. Asumirlo en América Latina no era una decisión sencilla: no tenía el aura gloriosa del marxismo ni prometía a utopía. Proponía una convivencia tolerante y lúcida entre las personas, una ciudadanía activa y alerta, el presagio no de una sociedad ideal sino de una vida civilizada." 


\section{India: One-Way Reception}

Octavio Paz lived in India for a long time: first in 1952, from January through June (when he was called to Tokyo), and then again as the Mexican ambassador to New Delhi from September 1962 through October 1968. One day after the October 2, 1968 massacre of peacefully demonstrating students in Tlatelolco, he resigned his office and left India, a country that without a doubt left an important mark on him and famously played a major role in his literary work.

The first edition of "Viento entero" ("The Wind from All Compass Points") was published in India in 1965 (New Delhi: The Caxton Press); this edition of the poem, which Paz prepared in tandem with the publisher, Om Parkash, is highly valued to this day. It was a small edition, of only 197 copies, which in 1965 circulated especially among Paz's friends in Mexico, the United States, and Asia (see Vargas 2014). This publication and the way in which it was distributed gives an indication that it was only particular circles that were reading Paz, while he was never read by a broad public in India. Although it would seem natural to assume that over the years, Paz's work could have met with a strong response, there is in fact no evidence of that. One place where one might expect to find such clues would be in the scholarly journal Hispanic Horizon, published by the Centre of Spanish Studies of Jawaharlal Nehru University, in New Delhi, whose first issue appeared in 1985. In the nine issues of the journal that appeared between 1985 and 1991, in addition to a lecture by Octavio Paz entitled "India and Latin America: A Dialogue of Cultures" (no. 3, 1986) - a lecture that he gave on November 13, 1985, as the 18th Jawaharlal Nehru Memorial Lecture there are only two items about him: an essay by R. S. Sharma on "The Indian Poems of Octavio Paz" (no. 5, 1987-1988) and a short note on "The ManySplendoured Genius of Octavio Paz" (no. 9, 1991), written by Susnighda Dey on the occasion of the bestowal of the Nobel Prize in Literature on Octavio Paz.

Sharma's essay comments on a number of poems from Ladera Este (Eastern Slope), arguing that India was not just an inspiration for Paz's poetry but in fact a veritable rebirth $^{120}$ and the beginning of a period of poetic maturity. Susnighda Dey, for his part, emphasizes the importance of Octavio Paz for Spanish-language literatures. He stresses the great variety in his work, but also comments on Paz's difficult relationship with Latin American leftism. These remarks illustrate one of the possible reasons why Octavio Paz was not interesting to India's intellectuals and writers. In Germany, for example, in spite of the transition in his political position that we have described, his work continued for a long time to be received

120 Paz himself used the image of his own rebirth in India in talking about meeting and marrying Marie José Tramini in India (see Lambert 2014: 25). 
in connection with leftist theory construction, along with that of other Latin American writers, but in India's postcolonial constellation it was apparently other writers, writers who unlike Paz represented an aesthetic and experience that was perceived as shared, who were found to be relatable. We can discover a hint to this trend by looking at which contemporary Spanish-language writers were much more strongly received in India than was Paz: Pablo Neruda, Gabriel García Márquez, Camilo José Cela, Federico García Lorca, César Vallejo, Juan Ramón Jimenez - these are the names that one repeatedly encounters when looking through Indian publications on Latin American or Spanish-language literatures from the second half of the 20th century. Even a later entry in Hispanic Horizon, “Octavio Paz in India” (no. 19, 2000), written by Edmundo Font who was himself also a Mexican ambassador, emphasizes once more how important India was for Octavio Paz but never mentions any possible influences of Octavio Paz on India.

We can also find six issues (from 1993-1995) of another journal from India, Hispanistica: Indian Journal of Spanish and Latin American Studies, which did not mention Paz at all in those years. In the 1995 collection Tierras lejanas, voces cercanas: estudios sobre el acercamiento indo-ibero-americano (Faraway lands, nearby voices: Studies on the Indo-Iberian-American connection), although there is indeed one essay about Octavio Paz and India, there is no indication of any ways in which Paz's work was received in India. In most publications on the subject - for example the volume Octavio Paz et l'Orient (Lambert 2014; Octavio Paz and the Orient) - it is mostly the influence of Indian experiences on Paz, the influence of Eastern ways of thinking, aesthetics, and religion on his work, that are discussed.

\section{Lines of Reception in Japan}

The situation is completely different in Japan, where Paz lived for not quite five months in 1952 (June 5 to October 29), a very short time. Mexico had broken off diplomatic relations with Japan in 1942, and Paz was sent to Tokyo in 1952 as the chargé d'affaires in order to reestablish the embassy. This was his first position of responsibility in the foreign service. This can also be seen from Paz's correspondence from the previous months, which were published a few years ago (see Asiain 2014a: 57). Aurelio Asiain writes very knowledgeably about Octavio Paz's experience in Japan and his connection with Japanese literature, thanks in part to Asiain's own five-year experience working for the Mexican embassy in Tokyo (Asiain 2014a: 60). Asiain points out that the short time Paz spent in Japan, as well as the position that he held there, were not the right conditions to allow him to establish any real contact with Japanese culture or with the 
people there, especially since Octavio Paz did not speak any Japanese. ${ }^{121}$ But Asiain nevertheless indicates the ways in which, before Paz's stay in Japan and also, in particular, afterwards, he repeatedly sought out connections with Japanese writers and subjects: "My passion for Chinese and Japanese poetry predates my first visit to the Orient. It began in late 1945, in New York" (Mi pasión por la poesía china y japonesa es anterior a mi primer viaje a Oriente. Comenzó a fines de 1945, en Nueva York), Paz wrote on the occasion of the death of José Juan Tablada, whose library had first prompted Paz to occupy himself with those literatures (cited in Asiain 2014b: 14). This is a reference to the first of three decisive phases that shaped Octavio Paz's interaction with Japan: Paz's return in 1945 to reading Tablada's work, which Paz credited with having introduced haiku into Spanish-language literature (see Lambert 2014: 18n3). The second phase is his reading of Daisetz Teitaro Suzuki's studies of Zen Buddhism in Paris, around 1950; the third is his 1952 stay in Japan and his reading and rereading of Chinese and Japanese poetry in English translation (Giraud 2014: 335-36).

During his long and successful career as a translator, the only book that Paz ever translated in its entirety was the volume Sendas de Oku (The Narrow Road to the Deep North) by the Japanese poet Matsuo Bashō (Asiain 2014b: 12; see also Lambert 2014: 489). Pivotal poems in Paz's collections Viento entero (Entire wind), Blanco (White), and El mono gramático (The monkey grammarian) are influenced by Japanese literary traditions, along with a number of shorter poems in Piedras sueltas (Loose pebbles) and the haikus in Árbol adentro (The tree within). Although, when discussing Paz's biography as well as his Asian influences, Japan is often mentioned more or less in the same breath with India, Japan was of course politically and culturally very different from the Indian subcontinent. Paz himself reports, at the beginning of his time in Japan, that the youth in Japan was very strongly oriented towards the lifestyle of the United States, as well as reporting a kind of astonishment at how the Japanese populace dealt with him as a Mexican diplomat and especially with influences from the United States:

Contrary to what I expected, I have not perceived any resentment against the North Americans. This could be a superficial impression, because the May Day incidents appear to prove otherwise. But I do not believe I am wrong in saying that I have found a state of mind that is very different from that to be found in Europe, especially in France: neither bitterness nor resentment. I do not sense any hatred of foreigners . . .. Nor is there anything to recall the atrocious misery of India - nor the reserve and distrust, almost always

121 On this topic, see also Paz's correspondence with Alfonso Reyes (cited in Lambert 2014: 20). 
masked as self-sufficiency, of the Hindu bureaucracy. The youth, from what I have seen in the streets, is very "Americanized." In no country is the influence of the manners and customs of our neighbors so visible. ${ }^{122}$

(Cited in Asiain 2014a: 61-62)

If we put aside these political and cultural constellations and preconditions, which do of course strongly distinguish India from Japan, the question that remains is: How, then, was Paz's work received in Japan, in a concrete way? Are there any indications that, also in his role as a liberal writer who could no longer be categorized as belonging to a leftist movement, he was assigned a different status by the Japanese public than he was, say, in India?

It is very clear that, independently of any concrete local networks, Paz was received much more intensively in Japan than in India. The translation statistics alone already show that in a general overview of all translations before and after the Nobel Prize, Japanese stands at a remarkable fifth place among all languages in the world. Aurelio Asiain, in his above-cited work, Octavio Paz en Japón, where he quotes from four Japanese translators of Paz's work, gives some information about the context, commenting that when he invited Paz's Japanese translators to an event at the Mexican embassy in 2002, he had more than twenty such translators to choose from. The fact that there were so many translators was positive, on the one hand, because it made clear the enormous interest that there was in Japan for Paz's work, but on the other hand it could also be seen in a negative light because it was an indication that that work was divided up among so many publishers and translators in Japan. There was no one publisher that had continuously devoted itself to Paz's complete works (Asiain 2014b: 324).

In the fall of 1952, after his short stay in Japan, Paz left the country, mostly because his wife was ill and needed further treatment in Europe. When he came to Japan for the second time, a lot of time had passed, time in which he had also engaged with Japanese literature. In 1984, then, Paz gave lectures at Keio University and Sofia University, two of Japan's most prestigious private universities. Keiko Imai, a scholar who wanted to hear Paz's lecture in 1984, recalls that the auditorium of Sofia University in Tokyo was overcrowded: "Some

122 "Contra lo que esperaba, no he percibido rencor contra los norteamericanos. Esta impresión puede ser superficial, pues los incidentes del primero de mayo parecen demostrar lo contrario. Pero no creo equivocarme al afirmar que he encontrado un estado de espíritu muy distinto al de Europa, especialmente al de Francia: ni amargura, ni resentimiento. No se percibe odio al extranjero . . . Tampoco nada que recuerde la atroz miseria de la India - ni la reserva y desconfianza, casi siempre enmascaradas de autosuficiencia, de la burocracia hindú. La juventud, por lo que he visto en las calles, se encuentra muy 'americanizada.' En ningún país es tan visible la influencia de las maneras y costumbres de nuestros vecinos.” 
people came from very far away, from Hokkaido and Okinawa. The lecture was supposed to begin at 6 p.m., but there had been people waiting since 6 o'clock in the morning. Paz is a very beloved author among the Japanese. He had not yet won the Nobel Prize" (Algunos vinieron de muy lejos, de Hokkaido y de Okinawa. La conferencia se inició a las seis de la tarde, pero desde las seis de la mañana había público esperando. Paz es un autor muy querido por los japoneses. Aún no le daban el premio Nobel; cited in Asiain 2014b: 323).

The contributions of the four translators allow us to deduce a few details about the history of Paz translation in Japan. Hidetaro Yoshida, a university professor, was already working on a Japanese edition of El laberinto de la soledad as early as the mid-1970s; the text was then published in 1979 by Shin sekaisha in Tokyo. Thus, when Norio Shimizu was commissioned by the Shinchosha publishing house to very quickly prepare a translation of El mono gramático in the mid1970s, Paz was still an unknown writer in Japan ${ }^{123}$ - at that point the only existing translation of the text was in French, but there was clearly a sense that it might meet with a certain amount of interest in Japan. It was only when the translator was already halfway through his work that he received a copy of the original Spanish-language version and realized how much had gotten lost in the transfer process from Spanish to French. Shimizu describes his own engagement with the French translation, including references to Hindu mythology and to Buddhism, and indicates what kinds of challenges were involved in the necessary cultural translation (Asiain 2014b: 325-26) before the text could be published in 1977.

Fumihiko Takemura, who translated Los hijos del limo (Children of the Mire) into Japanese in the early 1990s, also reports that the translation work was very stressful and challenging, and that it took three years before he was able to turn in the manuscript, but that that time was also very enriching to him as a translator. His words make it clear how thoroughly a translator has to internalize the poetology that Paz creates in order to be able to do this work. Fumihiko Takemura writes: "What surprised me, more than anything else, was the breadth of Octavio Paz's vision” (Me sorprendió, ante todo, la amplitud de la visión de Octavio Paz). He emphasizes what widely disparate realms of knowledge Paz brings together as well as the fact that the author succeeds in connecting very different cultural and historical points of view to central concepts in his own writing (Asiain 2014b: 326). Takemura goes on to explain: “As I was translating it, one characteristic of his style impressed me in particular: the parallel placement of nouns (nominal sentence construction), a device that in Japanese we call

123 Research could not confirm Norio Shimizu's recollection that El laberinto de la soledad was already available in Japanese when he started his translation work (cf. Asiain 2014b: 325). 
meishi-koobun or teigen-dome .... This peculiarity of Paz's writing produces lean sentences, with no fat. It brings prose closer to poetry, with clear logic" ( $A l$ traducirlo, me impresionó particularmente una característica de su estilo: la colocación paralela de los sustantivos [construcción sustantiva de oraciones], recurso llamado en japonés meishi-koobun o teigen-dome . ... Esta peculiaridad de la redacción de Paz produce oraciones esbeltas, sin grasa. Acerca la prosa al verso, con lógica clara; Asiain 2014b: 327). The way in which Paz's work is able to connect with Japanese tradition on various levels - in terms of both content and style - plays as important a role here as does the integration of the most varied traditions and perspectives into his poetology.

Finally, the descriptions by the most "current" of the Paz translators on the panel of experts, Fumiaki Noya (b. 1948) - who was a former professor at the Rikkyo University, Waseda University, and the University of Tokyo (that last one a state school), and who at the time of the conversation had just completed a translation of Águila o sol - are enlightening. Noya was very well known in Japan at that time as an expert on Latin American literatures, and in addition to Paz, he had also translated the work of Borges, Neruda, Cortázar, García Márquez, Vargas Llosa, Puig, and Bolaño. He says that his interest in Paz, and the particular energy that translating Paz gives to him, comes not so much from Paz's literature but rather from a character trait of Paz's himself that shaped his life and literature: "What encourages me is, more precisely, his courage. As much in his life as in his writing, Paz was very courageous. It is a courage that is in his language, but also in episodes of his life" (Lo que me anima es, más precisamente, su valentía. Tanto en su vida como en su escritura Paz ha sido muy valiente. Es una valentía que está en su lenguaje, pero también en episodios de su vida; Asiain 2014b: 332). He tells the story of an episode from the time when Paz was writing Águila o sol in Paris: when he met Jean Paul Sartre, whom many intellectuals had so uncritically fallen for, Paz, as a completely unknown writer in Paris, dared to accuse Sartre of writing about Spanish affairs and Spanish-language literature without knowing anything about them (see Asiain 2014b: 333). Fumiaki Noya explains his perspective on Paz like this: "Many people attacked and reviled him. But nevertheless, his posture was always consistent. What impressed me is this and, thanks to the presence of Paz, I feel that I can be at peace even when I am alone. This is what I feel when I dedicate myself to the translation" (Fue atacado y denostado por muchos. Aun así, su postura fue siempre coherente. Lo que me ha impresionado es eso y, gracias a la presencia de Paz, siento que puedo estar tranquilo aunque esté yo solo. Eso es lo que yo siento al dedicarme a la traducción; ibid.). Noya goes on to say that at the end of discussions about Paz, people usually say how exceptional his literature is ("they often end with people affirming that Paz is excellent”; muchas veces se termina afirmando que Paz era excelente; ibid.), but 
that he has to say that Paz, too, has his limits, his mistakes, that should not be ignored. In a sense, he turns the reproach that Paz once made to Sartre back against Paz: "With respect to Japanese literature, Paz did not know very much, but he translated a few works" (A propósito de la literatura japonesa, Paz no tuvo muchos conocimientos pero hizo la traducción de algunas obras; ibid.).

In other words, one of Japan's most influential and knowledgeable translators of Paz's work does not stress the content-related connections of Paz's writing to Japanese literary traditions, as has often been done in scholarly contexts (cf., for example, Giraud 2014). Instead, what he brings out is the significance of the personal stance that Paz achieved in the context of his work and his career and which then flowed into his work, a kind of individual intellectual vision that also, for Noya, distinguishes Paz from other writers. Here, again, the extra-literary aspects are decisive in highlighting Paz's significance for the Japanese context.

\section{IV.2.6 Octavio Paz as an Intellectual Figure in the Global Context and the Epochal Change of 1989-90}

In conclusion, when we look at all of the prizes and awards that shaped Paz's career as a world literary figure, it becomes clear that the significance of the intellectual presence that is Octavio Paz, to which the Japanese translator Fumiaki Noya was referring, can also be seen from yet another, more comprehensive, perspective. The prizes that Paz won before 1968 were the Xavier Villaurrutia Prize in Mexico, in 1956, for El arco y la lira, and the Grand Prize of the Biennales Internationales de Poésie of Belgium's International House of Poetry, in 1963, for his poetry. After 1968, however, his international awards multiplied. Even aside from the ten honorary doctorates that were bestowed on him between 1973 and 1995, Paz was awarded sixteen international prizes and awards (including the Nobel Prize in Literature). Of these sixteen, which are ostensibly connected with literature, only three of them are primarily based on his poetry (the 1972 Flanders Poetry Festival Prize, the 1982 Neustadt Prize for Literature, and the 1985 Oslo Poetry Prize). The other thirteen pay tribute to his entire oeuvre and, especially, the role that Octavio Paz plays in society as an intellectual. Among these, I would particularly point out the Jerusalem Prize for the Freedom of the Individual in Society (1977), the Miguel de Cervantes Prize (1981), the German Book Trade Peace Prize (1984), the Alexis de Tocqueville Prize (1989), and of course the Nobel Prize in Literature (1990). And if we look at the rationales for these prizes and awards, insofar as they are available, as well as Paz's own speeches upon accepting them, we can reconstruct Paz as an intellectual "figure" that he himself created 
and that, as could be seen throughout the various stages of his career, became a central foundation for the worldwide reception and interpretation of his work beginning in the late 1970s. In his speeches, Paz defended the position of poetry in the modern world, from a variety of perspectives, and he repeatedly emphasized how essential the practice of poetry is for the achievement of freedom, peace, and democracy. His statements on the occasion of his various prizes can also be connected with the respective world political contexts, for instance with the international tensions of the Cold War and the extreme polarization that took place in many countries in the 1960s and 1970s.

In his reflection on the awarding of the Nobel Prize in Literature to different Latin American writers, Santiago Roncagliolo writes about Octavio Paz: "He was the first [Latin American] honoree since Asturias who was not a committed revolutionary but was instead quite the opposite, a representative of liberal thinking." Roncagliolo also returns to the influence of Artur Lundkvist, the Swedish poet and critic who translated Paz so early on and then later became a member of the award committee for the Nobel Prize in Literature. According to Roncagliolo, Artur Lundkvist's appreciation of Latin American literatures also owed a lot to his leftist politics; I have already discussed the demand for a way to combine aesthetics with leftist theorizing, which allowed Latin American writers of the 1960s, 1970s, and 1980s to break through onto the world stage. Roncagliolo calls Lundkvist a "friend of Neruda's with Communist sympathies." Lundkvist died in December of 1991 after having been very ill for a while, and he was no longer an active member of the Swedish Academy when Paz won the Nobel Prize in the fall of 1990. Roncagliolo understands Lundkvist's death at that point in time "as a metaphor for a turning point” after which the muchvaunted revolutionary Latin America - to which Lundkvist had so dedicated himself and to which, according to Roncagliolo, the previous Latin American Nobel laureates in literature had belonged - no longer existed in the same form. The fact that Paz was awarded the Nobel Prize in Literature at such a politically pivotal time, in 1990, when the Soviet Union was disintegrating, was "like a portent of the new world order" (Roncagliolo 2011). The choice of Paz, again according to Roncagliolo, turned out to be prophetic, because after the Berlin Wall fell, the liberal democracies in Latin America stabilized, except in Cuba, and the kind of dictatorial figures that García Márquez and Asturias had described were wiped off the map. This is the context for the comments that Isaac Bazié compiled by literary critics from France, Germany, and the English press on the award of the Nobel Prize to Paz: the key catchphrases are an "aesthetic cosmopolitanism” (ästhetischer Kosmopolitismus) and Paz's "profile as a citizen of the world" (weltbürgerliches Profil; Bazié 1999: 85, 93), which were consistently praised in the press and which provide the basis for the unusually 
broad consensus in the Western press on a positive reaction to the Nobel Prize decision. A similar line of reception could be ascertained in Japan, whereas in India, it was not the same. In sum, we can say that through the connection of his literary work with his strong extra-literary activities, Paz had acquired a reputation as a liberal cosmopolitan intellectual who would be in a position to comment on the great political changes of the years that followed 1989-90, with their global consequences.

\section{IV.3 Julio Cortázar’s World Literary Success: Between Translation Work and Politics}

To address the guiding question of this study, How is World Literature Made?, let us, finally, look at the work of one more writer for whom there is enough material available that we can address the global contexts of circulation processes, but who also forged his own path: Julio Cortázar. ${ }^{124}$ Here again, using our findings on Paz and García Márquez, we can work out clearly definable factors that were responsible for the worldwide reception of Latin American writers.

Although Julio Cortázar is one of the Boom writers, and his novel Rayuela (1963; Hopscotch) is one of the best-known texts of the Boom in the world today, his international reception history did not begin with any kind of large sales success, as it did for García Márquez with Cien años de soledad. Fernando Estévez, the editor-in-chief at Alfaguara, counts Cortázar as one of the long sellers, authors whose sales figures are not so enormous over a short time span but who have a permanent readership (Guerriero 2001). ${ }^{125}$ Peter Standish lists three contributing factors for Cortázar's significance: first, the quality of his literary output, especially of his short stories and of his novel Rayuela; second, the diversity of that output, which was often hard to categorize into traditional literary genres; and third, the fact that he became politically active, relatively late, and was a well-known and controversial character (Standish 2001: xi). How, then, did these various factors play into the circulation and reception of his work?

Rayuela, the Cortázar text that undoubtedly stands at the center of the worldwide success of his literature (even if it is not the only one), has been

124 I would like to thank Vicente Bernaschina Schürmann and Katharina Einert for important information in this context.

125 According to Estévez, as of 2001, the total sales of all of Cortázar's works that had been published by Alfaguara came to 200,000 (Guerriero 2001). 
translated into more than thirty languages, in spite of the fact that the complex structure of the text, as well as Cortázar's linguistic inventions (including his invented language el glíglico), make the translation of his work so much more difficult. The publication dates of the translation allow us to trace the stages of Cortázar's reception as proceeding across the world from Argentina, to Paris, to the United States, and then to other countries. The fact that Cortázar was writing straight from Paris, even though his works were initially published in Buenos Aires, is an important part of the background for the fact that Paris played a more important role in the reception and diffusion of his works than did Barcelona. What follows is a closer analysis of the contexts for the international circulation history of his works, with a particularly close look at his letters. Because Cortázar himself collaborated on several of the translations of Rayuela into other languages, and maintained lively correspondences, this material is exceptionally valuable in his case and, at the same time, indicates which of the relatively early stages of his reception in Europe and the United States we will need to emphasize most. Determining the global dimension of his reception by, for instance, using the South-South axes as a guide, would be impossible or at least very inadequate, based on the material available on Cortázar.

If we look through Cortázar's correspondence beginning in the early 1950s or, more precisely, since the publication of Bestiario (1951; Bestiary), we can follow, in great detail, the way in which he tried to make his work known abroad using intensively cultivated contacts and friendships. At first, it was particularly his contacts in France (where Cortázar lived from 1951 on), Mexico, Argentina, the United States, and Germany that were noteworthy; then, starting in the early 1960s, Italy begins to be mentioned, and later there are increasing numbers of translations into languages that Cortázar himself did not speak.

From the early letters of the 1950s we can reconstruct how Cortázar built up his connections with translators. First he met a French-Uruguayan couple, Marta Llovet and Jean Barnabé, in Montevideo, and their friendship gave rise to the first attempts to translate his stories into French and have them published. After Barnabé's French translations failed, Cortázar found a new translator, Laure Guille-Bataillon. Then, with his eye on the United States, Cortázar used his contact with the poet and translator Paul Blackburn, who soon also began to function as a literary agent, to distribute his stories in the United States. The translator Edith Aron, whom Cortázar knew personally, first made his work known in Germany and was behind his success there. In the 1960s, in order to make Rayuela accessible in other languages beyond Spanish, Cortázar worked intensively not only with the French translator Laure Guille-Bataillon but also with Gregory Rabassa, who translated the novel into English; then Cortázar worked on the Italian translation, which was an extremely time-consuming 
undertaking that completely occupied him at times. At one point he apologized to Rabassa for a delay, explaining that he had had to devote himself to some work on the French translation first. He wrote: "Then I had to take a break, because this book of mine is already starting to provoke revulsion in me just from opening and closing it all the time in order to respond to all the problems that these revisions raise" (después tuve que descansar, porque este libro mío ya empieza a darme asco a fuerza de abrirlo y cerrarlo todo el tiempo para responder a todos los problemas que me plantean estas revisiones; Cortázar 2012c: 119). The international success that Rayuela has enjoyed over the course of the years can be attributed not least to Cortázar's intensive efforts to assure that the translations would be up to the standards of the original.

\section{IV.3.1 Julio Cortázar: Reception Paths}

Cortázar achieved his first breakthrough between 1959 and 1960, with the almost simultaneous publication of Las armas secretas (The Secret Weapons) and Los premios (The Winners) with the Sudamericana publishing house in Argentina. Both books sold very well in Argentina. Los premios was then quickly translated into French, followed by inquiries from England and the United States. But Cortázar had to fight for years in order to get a collection of short stories published, in both France and the United States.

Rayuela appeared in Buenos Aires, also published by Sudamericana, on June 28, 1963. Michi Strausfeld had this to say about the significance of this work: "Rayuela changed an entire generation of readers and writers. It had the most influence that you can possibly imagine a book having because it changed the reading habits of an entire continent, plus Spain" (Rayuela hat eine ganze Generation von Lesern und Autoren verändert. Es hat den größten Einfluss ausgeübt, den man sich von einem Buch nur vorstellen kann, weil es die Lesegewohnheiten eines Kontinents plus Spanien verändert hat; quoted in Karnofsky 2014: 14). According to Rowan van Meurs, the novel is considered a pioneer of European postmodernism, putting an end to realism and its concepts. The use of the made-up language el glíglico, van Meurs writes, stands for resistance to a language that is nothing but a product of conventions. The anachronistic order and the fantastical elements that are present in Rayuela, among other texts, underscore the innovative character and pleasure in experimentation that mark Cortázar's works (van Meurs 2014: 14-15). Michael Rössner stresses Cortázar's development leading up to Rayuela: 
In the 1963 novel, the tendencies of all of the author's earlier works converge: those of the fantastical short story that wants to encourage the reader to question the apparent order of their environment through its "corrective disorder," as well as those of the longer narratives in search of a center or of a paradise called "the other."126

(Rössner 2009: 216)

On the ability of the novel to connect to European cultural traditions, he writes:

The completely disillusioned Argentine Oliveira is familiar with and quotes from Hofmannsthal's "Letter of Lord Chandos" as well as Musil's Confusions of Young Törleß and The Man Without Qualities; he is positioned within a cultural tradition that was taken over from Europe and in which the crisis phenomena of the early 20th century persist. ${ }^{127}$ (ibid.)

Rössner draws parallels with surrealism and describes Rayuela as "an experiment that concerns the whole person, that marries the Latin American search for identity with the European discomfort with culture" (ein Experiment, das den ganzen Menschen angeht, das lateinamerikanische Identitätssuche mit europäischem Unbehagen an der Kultur verbindet; 217). What is of course very central to the reception of the novel is Cortázar's idea that a text is newly produced with every reader and that it only exists through active reading - the deconstruction of formal novelistic conventions.

In Julio Cortázar en los Países Bajos, van Meurs writes that Cortázar's works are very accessible to the European readership because those readers can easily identify with the characters, who come from metropolises like Buenos Aires or Paris, and that because the author had lived for a long time both in Argentina and in Europe, he was able to combine both worlds in a universal work (van Meurs 2014: 15). This brings up further questions: In what way was Rayuela, given this background, received in the United States, which is so important for an international circulation? Are there fundamental differences between the reception in the United States and the early reception in Europe? The question of further "specific" reception contexts, with their own reception paths, is of course also of interest.

In Nicaragua, for instance, the political positioning and the reception of the novel lined up: Rayuela was received very intensively there, especially among

126 "In dem 1963 erschienenen Roman laufen die Tendenzen aller früheren Werke des Autors zusammen: der phantastischen Kurzerzählung, die durch ihre 'berichtigende Unordnung' den Leser zu einem Infragestellen der Scheinordnung seiner Lebenswelt anregen will, ebenso wie der längeren Erzähltexte auf der Suche nach einem 'Zentrum' oder 'das Andere' genannten Paradies.”

127 "Der völlig desillusionierte Argentinier Oliveira kennt und zitiert Hofmannsthals 'Brief des Lord Chandos’ ebenso wie Musils Törleß und den Mann ohne Eigenschaften; er steht in einer von Europa übernommenen Kulturtradition, in der die Krisenphänomene des beginnenden 20. Jh.s fortwirken." 
the Sandinistas. When Rayuela was first published, Sergio Ramírez, later a Sandinista revolutionary and then the vice president of Nicaragua, was a 21-yearold student. He reported:

For my generation, Rayuela was our Bible for matters of behavior. Rayuela was not a political novel, but a novel that suggested dynamiting the bourgeois world, the world as it was then, the traditional values. And from that perspective, it was a very educational book. It stood for nonconformism. It was about breaking out of the old forms, which was what we Sandinistas also did. Acting differently. I think that in that sense, Rayuela was, aside from its literary value, a generationally specific reading for rebellion, a book of anarchistic suggestions, I would say. Because Rayuela only suggests a de-construction of the world, and not its rebuilding. ${ }^{128}$

(Karnofsky 2014: 13)

We can presume that it is this nonconformist element that was also strongly recognized in other countries of the Global South. In China, for example, the book first appeared in 1996. ${ }^{129}$ A few of the original Spanish-language editions in Latin America are crucial for understanding the circulation history of Cortázar's literature and certain related paths that its reception took.

\section{IV.3.2 Precursor to Success in Argentina: Mexico}

In spite of the resounding success he had in the 1960s, especially in 1963 with Rayuela, Cortázar was by no means so successful in Argentina to begin with. In his letters from the mid-1950s, he reports on great enthusiasm in Mexico for his literature, as well as on his attempts to become more widely published in Argentina. In a letter dated May 27, 1956, Cortázar wrote to Eduardo Jonquières, the Argentine painter, that the Mexicans were apparently so excited about him that they were even interested in his novel El examen (which was ultimately only published posthumously):

128 "Für meine Generation war Rayuela eine Bibel, was das Verhalten anbelangt. Rayuela war kein politischer Roman, aber ein Roman, der vorschlug, eine Ladung Dynamit an die bürgerliche Welt zu legen, an die Welt, wie sie damals war, an die althergebrachten Werte. Und aus dieser Perspektive war es ein sehr lehrreiches Buch. Es stand für Nonkonformismus. Es ging darum, wie wir Sandinisten es ja auch gemacht haben, die alten Formen aufzubrechen. Sich anders zu verhalten. Ich glaube, in diesem Sinne war Rayuela, von den literarischen Werten abgesehen, eine generationenspezifische Lektüre der Rebellion, ein Buch von anarchischen Vorschlägen, würde ich sagen. Denn Rayuela schlägt nur eine De-Konstruktion der Welt vor, nicht deren Neuaufbau."

129 See the piece "Una Rayuela china" (A Chinese hopscotch) that appeared in May, 1996 in La Nación. For countries such as China and Russia, we do not have enough data to be able to draw broader conclusions, and so I do not go into that topic any further here. 
The other news is that in Mexico, they have been enthusiastic about that novel that you know (El examen [The exam]), and it looks like they are going to ask me to edit it. Although it is now already old, I would still like for it to be published; it would be an a posteriori vision of the Peronist hell. It's just that people won't believe that it was written earlier, but I suppose some friend will write a kind of prologue-certificate, solemnly swearing that he read the originals in $1950 .{ }^{130}$

(Cortázar 2012b: 93)

Other comments and questions that Cortázar wrote to Jonquières on October 10, 1956 tend in a similar direction. At the end of the letter, Cortázar writes that he has heard that Goyanarte is publishing a good magazine in Argentina, in book form. ${ }^{131}$ Cortázar says he would like to send a long story (probably "El perseguidor" [“The Pursuer"], because he keeps talking about it in the previous letters) to that magazine rather than to Mexico: "I have a very long story (60 pages!!) that I think is very good. I would like to publish it in Argentina, rather than in Mexico, where they are asking me for it” (Tengo un cuento muy largo [60 páginas!!] que me parece muy bueno. Me gustaría publicarlo en la Argentina y no en México, donde me lo piden; Cortázar 2012b: 109). In 1956, we can conclude from these descriptions, Cortázar was already a sought-after author in Mexico, while in Argentina he was still largely unknown. "El perseguidor" ended up being published in the Revista Mexicana de Literatura (issue 9.10) in 1957.

On May 9, 1957, Cortázar wrote to Eduardo Hugo Castagnino to report that his stories had been very well received in Mexico. He also mentioned that there were two Argentines who were important advocates of his in Mexico at that time:

I was glad to hear that you liked my book. In Mexico it has been received extremely well to such an extent that a book has just come out by two Argentines who live and teach there (Emma Speratti and Ana Barrenechea), dedicated to the literature of the fantastic in Argentina. They devote a chapter to each of Lugones, Quiroga, Macedonio, Borges, and your own correspondent. It is not a small honor, and it has left me stunned. ${ }^{132}$

(Cortázar 2012b: 130)

130 "La otra noticia es que en México se han entusiasmado con aquella novela que conoces (El examen) y parece que me la van a pedir para editarla. Aunque ya vieja, lo mismo me gusta que se publique; será una visión a posteriori del infierno peronista. Sólo que la gente no creerá que fue escrita antes, pero supongo que algún amigo escribirá una especie de prólogo-certificado, jurando solemnemente que leyó los originales en 1950.”

131 The magazine is Ficción (a quarterly magazine book), published by Juan Goyanarte, whose first issue appeared in Buenos Aires in April/May 1956.

132 "Me alegró saber que mi libro te había gustado. En México ha caído más que bien. A un punto tal que acaba de salir un libro de dos argentinas que viven y enseñan allá (Emma Speratti y Ana Barrenechea), dedicado a la literatura fantástica en la Argentina. En sendos capítulos, se ocupan de Lugones, Quiroga, Macedonio, Borges y el que te escribe. El honor no es pequeño, y me ha dejado turulato." 


\section{IV.3.3 First Phase of Reception: Argentina}

With the almost simultaneous publication of Las armas secretas and Los premios in Argentina in 1959 and 1960, Cortázar became known to a broader public for the first time, which then greeted the publication of Rayuela in 1963 with an enormous response. Cortázar commented on how important it was to him that the Argentine novel Rayuela was so successful there. According to a magazine survey of booksellers, there had not been a homegrown bestseller in Argentina for twenty years: "One of our own books comes out and for a few weeks it leaves Huxley and Moravia behind” (Por ahí salga un libro nuestro y por unas semanas lo deje atrás a un Huxley o a un Moravia), Cortázar wrote to his Sudamericana publisher Paco Porrúa on August 11, 1963 (2012b: 425-26). On September 13, 1963, he continued in the same vein, reporting that he constantly received letters from young people in Argentina "who feel as though they have been beaten to death after reading it [the book Rayuela] and who write me their bewilderment, their gratitude (mixed with hate and love and resentment)" (que están como muertos a palos después de haberlo leído y me escriben su desconcierto, su gratitud [mezclada con odio y amor y resentimiento]; 430). He described something similar to Ana María Barrenechea on October 21, 1963:

Listen, ever since my book appeared in Buenos Aires, I have received and continue to receive a lot of letters, especially from young and unknown people, in which they tell me things that would be enough to make me feel justified as a writer . . .. They prove to me that Rayuela has the emetic qualities that I wanted to give it, and that it is like a fierce shaking by the lapels, a shout of warning, a call to the necessary disorder. ${ }^{133}$ (2012b: 433)

Cortázar's first wife, Aurora Bernárdez, talked about this transition towards a younger reading public for Rayuela:

Cortázar is a great storyteller. And then came Rayuela. The problem was that an author who had written stories was supposed to stick with that, as far as the readers of his generation were concerned. But there were also other readers, the young readers of the day. The response from them was unanimous. From the twenty-year-olds. And Julio wrote Rayuela for the forty-year-olds, but no, it was the twenty-year-olds who accepted it. And to this day, it is the twenty-year-olds who read it. ${ }^{134}$

(quoted in Karnofsky 2014: 13)

133 "Mira, desde que mi libro apareció en Buenos Aires, he recibido y recibo muchas cartas, sobre todo de gente joven y desconocida, donde me dicen cosas que bastarían para sentirme justificado como escritor . . .. Me prueban que Rayuela tiene las calidades de emético que quise darle, y que es como un feroz sacudón por las solapas, un grito de alerta, una llamada al desorden necesario."

134 "Cortázar ist ein großartiger Geschichten-Erzähler. Und dann kam Rayuela. Das Problem war, dass ein Autor, der Geschichten geschrieben hat, aus Sicht der Leser seiner Generation 
Cortázar himself told Paco Porrúa about some of the arguments that Rayuela provoked in Argentina. On October 29, 1963, he wrote to Porrúa:

The funniest thing is the impressive mess that was put together in El Escarabajo de Oro [The golden beetle, a literary magazine published by Abelardo Castillo]. Before I went to Vienna, I received a letter from Arnoldo Liberman praising the book and calling me a beast, an animal, etc., the fashionable vocabulary for hiding emotion. Then a letter arrived from Abelardo Castillo, more moderate but equally enthusiastic. And now, on my return, I find a review by Mrs. Liliana Heker that throws me up against the wall, along with a letter from Liberman letting me know that he has resigned from the co-editorship of the magazine to register his disagreement with that review. In other words, as you can see, the spiritual aggression that the novel intended has begun to manifest itself in some places. ${ }^{135}$

(2012b: 438-39)

In the context of an inquiry from the United States, he wrote to his United States agent and translator Paul Blackburn that Rayuela was "what you would call a scream in Argentina, a best-seller and a matter of scandal, literary rows and never-ending polemics” (2012b: 447).

\section{IV.3.4 Second Phase of Reception: France}

Cortázar's efforts to arrange translations into French began in the 1950s, after he had moved to Paris in 1951. On October 10, 1956 he told Eduardo Jonquières that he had received translations of his stories into French from Jean Barnabé and in collaboration with Barnabé, Cortázar tried to get the story collection Bestiario published in France as well. Cortázar intended to propose these translations for publication to an editor at Plon (Cortázar 2012b: 108). But it turned out that his contact no longer worked at Plon.

auch dabei hätte bleiben sollen. Aber es gab auch andere Leser, die jungen Leser jener Zeit. Bei denen war die Reaktion einmütig. Bei den Zwanzigjährigen. Dabei hat Julio Rayuela für die Vierzigjährigen geschrieben, aber nein, es waren die Zwanzigjährigen, die ihn annahmen. Und bis heute lesen ihn die Zwanzigjährigen.”

135 "Lo más divertido es el despelote imponente que se armó en El Escarabajo de Oro. Antes de irme a Viena recibí carta de Arnoldo Liberman elogiando el libro y tratándome de bestia, animal, etc., el vocabulario a la moda para disimular la emoción. Después llegó una carta de Abelardo Castillo, más moderada pero igualmente entusiasta. Y ahora a la vuelta me encuentro con una reseña de la señora Liliana Heker que me sacude contra las cuerdas, y una carta de Liberman donde me anuncia que ha renunciado a la co-dirección de la revista en señal de la discrepancia con esa nota. O sea, como ves, la agresión espiritual que pretendía la novela empieza a manifestarse en algunos sectores.” 
Four days later, on October 14, 1956, Cortázar wrote directly to Jean Barnabé to bring him up to date. According to Roger Caillois, at Gallimard, to whom Cortázar had personally taken the stories, they had no chance on the French book market:

[Caillois] told me that from an editorial point of view, he doesn't believe that there is anything that can be done, because when French publishers hear the word "short stories," they take out their revolvers. The readers here only like novels. But he added that, for now, he was going to read the translations, choose one or two of the stories, and have them published "in magazines." 136

(Cortázar 2012b: 110)

He also reported that he had sent the stories to Éditions du Rocher, in Monaco, because there was a woman who worked there who was apparently very interested in texts from the Río de la Plata area (ibid.). Then, on May 8, 1957, in a new letter to Jean Barnabé, Cortázar reported on the failure of their plan to get Bestiario published in French:

I believe I told you in my last letter . . . that I had taken Bestiaire to Caillois. He returned it to me, saying that he thought the translations seemed to him to be "too close to the original" (sic). When I asked him to explain what he meant, he maintained that you had been "too faithful" in some things, departing from French in order to stay closer to the Spanish twist, the rhythm of the phrase, etc . . ..; apparently, people like Caillois consider that the author is not of any great interest: the only thing that matters is to save the GRRRAANNND French style at all costs, the French way of saying things . . . even at the risk of any kind of betrayal. ${ }^{137}$

A few lines later, Cortázar explained that the biggest problem is not these adjustments to the translations but rather that this is a collection of short stories by an author who is unknown in France (ibid.). A week later, Caillois informed Cortázar that he had chosen the story "La noche boca arriba" ("The Night Face Up") to publish in an anthology. But for this anthology, the text was translated by someone else, namely René L. F. Durand (Cortázar 2012b: 126). In a letter to

136 "Me dijo que desde el punto de vista editorial él cree que no hay nada que hacer, porque los editores franceses cuando oyen hablar de cuentos sacan el revolver. Los lectores de aquí sólo gustan de las novelas. Pero agregó que, por el momento, iba a leer las traducciones, escoger uno o dos cuentos, y hacerlos publicar 'en revistas.”'

137 "Creo haberle dicho en mi carta anterior . . . que le llevé Bestiaire a Caillois. Me lo devolvió diciéndome que las traducciones le parecían 'demasiado apegadas al original' (sic). Cuando le pedí que me aclarara lo que quería decir, sostuvo que usted había sido 'demasiado fiel' en algunas cosas, alejándose del francés para mantenerse más cerca del giro español, del ritmo de la frase, etc . . ..; evidentemente la gente como Caillois considera que el autor no interesa gran cosa: lo único que cuenta es salvar a toda costa el GRRRAANNN estilo francés, la manera francesa de decir las cosas . . . aun a riesgo de cualquier traición.” 
Jean Barnabé dated August 7, 1957, Cortázar thanked him for his authorization to allow the translations to be checked and modified.

In any case, against my will, I accept your opinion and the full powers that you have given me, so generously: the translations are already in the hands of Miss Laure Guille, a professional translator and excellent person, who has promised to read them and to compare them to the original. Since she likes my stories, . . . I think that she will give us a good perspective à la française. ${ }^{138}$

After the double publication of Las armas secretas and Los premios in Argentina in 1959 and 1960, Cortázar then succeeded in publishing both volumes in France as well. He had been trying to get short stories published by Gallimard for nine years before Les armes secrètes came out with them in 1963, in the translation by Laure Guille-Bataillon. On April 20, 1963, Cortázar thanked his translator, with whom he had worked together closely, for the news that the book had been published, and asked for two copies. One of them, the letter makes clear, was for him to send to Jean Barnabé in Uruguay. Cortázar had dedicated the volume to him: Barnabé was the first person who had tried to translate Cortázar into French. Les gagnants achieved unexpected success in France. Against the background given here of the attempts to get the stories published, the success of Les gagnants in France should certainly also be viewed critically it is notable, at the very least, that a text that can under no circumstances be considered one of the author's strongest initially met with a more positive response than did some of Cortázar's best short stories (for example "El perseguidor," which had since appeared in the short story collection Les armes secrètes). His text Rayuela, which was later celebrated as a novel of the century and which broke so thoroughly with narrative conventions, was also not at first easy to get accepted by his French publisher.

In a letter to Francisco Porrúa dated August 14, 1961, Cortázar first commented on the success that Los premios appeared to be having in France, while in Latin America there were still critical voices, such as that of Ángel Rama:

Here, the French are still talking [with respect to Les gagnants] about Huxley, just because it was mentioned on the flap, which proves that "criticism" is not that different from one latitude to another. They have treated me with an almost tropical generosity; but luckily, in among all those compliments, I received Rama's review in Marcha, where he takes me

138 "De todos modos acepto contra mi voluntad su opinión y los plenos poderes que me da usted, tan generosamente: las traducciones ya están en manos de Mlle. Laure Guille, traductora profesional y excelente persona, quien ha prometido leerlas y cotejarlas con el original. Como le gustan mis cuentos . . . pienso que podrá darnos un buen punto de vista à la française." 
to task severely. The young man is trying to say something that I would like to understand better, but I have not really been able to figure out why he does not like the book . . .. If I go to Montevideo, I will buy him a cup of coffee at Tupinambá, and maybe I will learn something useful. Speaking of Montevideo, I got one of the best rewards of my life: a letter from Onetti in which he tells me that "El perseguidor" gave him a rough two weeks. For me, that's like telling me Musil or Malco[1]m Lowry, that category of planets. ${ }^{139}$

(Cortázar 2012b: 248)

What was remarkable in those years was the circulation of Historias de cronopios y de famas (Cronopios and Famas). Although these prose pieces - with which Cortázar invented his very own genre - did not appear as a book in Argentina until 1962, they had already circulated to great success in France and in the United States in the form of magazine publications. ${ }^{140}$ In addition to his reputation as a writer of fantastical literature, Cortázar now showed a humorous, somewhat Dadaist side that was to bring him many literary admirers. Michi Strausfeld wrote about the connection between these texts and the public perception of their author:

It was during a concert in Paris that he got the idea for the "cronopios," those "wet green thingies": they are bristly, messy, and casual, dreamy and intuitive, poetic nonconformists, trusting optimists, humorous bon vivants, best friends, who can carry on philosophical nonsense dialogues. Many people see in them the author's vital alter ego. Cronopios never use lined paper for writing, and nor do they squeeze the toothpaste tube from the bottom to the top. For all of his fans, the cronopios became the epitome of Cortázar, of his view of the world.

He himself is the greatest cronopio. He always looked like a lanky youth, in spite of his height (well over six feet), and he never seemed to age. His blue eyes were set wide apart, registering everything, as he listened modestly and carefully hid his encyclopedic knowledge. His guttural "r" was striking, a legacy of Brussels, as he said. ${ }^{141}$

(Strausfeld 2014)

139 “Aquí los franceses siguen hablando de Huxley, simplemente porque se lo mencionaba en la solapa, lo cual prueba que la 'crítica' no varía mucho de una latitud a otra. Han sido de una generosidad casi tropical conmigo; menos mal que entre tantos elogios me llegó la nota de Rama en Marcha, donde me sacude severamente contra las sogas. El mozo quiere decir algo que a mí me gustaría comprender mejor, pero no he podido darme bien cuenta por qué el libro no le gusta . . .. Si voy a Montevideo le pagaré un café en el Tupinambá, y a lo mejor aprendo cosas útiles. Hablando de Montevideo, tuve una de las mejores recompensas de mi vida: una carta de Onetti en la que me dice que 'El perseguidor' lo tuvo quince días a mal traer. Para mí es como si me lo hubiera dicho Musil o Malcom Lowry, esa clase de planetas.”

140 For example with Olympia Press, which put out a magazine that appeared monthly in Paris, London, and New York and had a circulation of sixty thousand copies (see Cortázar 2012b: 251).

141 'Während eines Konzerts in Paris kam ihm die Idee zu den 'Cronopien,' jenen 'nassgrünen Dingerchen': Borstig sind sie, unordentlich und lässig, verträumt und intuitiv, poetische 
Historias de cronopios y de famas appeared in Argentina as a monograph in 1962, just a few months before Rayuela, on which Julio Cortázar had worked intensively for four years. In a letter dated October 29, 1963, he described to Paco Porrúa why he thought it was that getting Rayuela published with Gallimard was not as easy as one might have assumed given the history in France and also the urgent inquiries from the United States, for instance, about buying the rights to Rayuela:

And now I move on to something very private, but you need to know about it because it surpasses everything in terms of being inconceivably distasteful. You know that Gallimard is considering Rayuela. You know that the original typescript of the book was submitted to Roger Caillois a year ago. You don't know (but now you do) that Caillois hasn't read it, for the simple reason that Caillois is not able to read Spanish; he can barely get beyond the syntactic rigor of a prose like Borges's. At any rate, Miss Monique Lange, who is in charge of Latin American editions and is fervent to the point of delirium about Les armes secrètes, has just told a close friend of mine that Gallimard probably won't publish Rayuela because Caillois has vetoed it. ${ }^{142}$

(Cortázar 2012b: 441)

Cortázar then went on to speculate about the backgrounds and contexts for such a decision, bringing up literary as well as political aspects:

Can you see the machine working? The first gear is engaged in B.A., of course, and it's called whatever you want, the group from the Sur, right-thinking people, guardians-ofcorrect-and-curseless-language; it is called, most of all, DELENDA EST COMUNISMUS [Communism must be destroyed]. Your nice anecdote of a few months ago about V. O. [Victoria Ocampo] meshes closely with this school. To say Caillois is to say V. O. And

Nonkonformisten, vertrauensvolle Optimisten, humorvolle Lebenskünstler, beste Freunde, die philosophische Nonsens-Dialoge führen können. Viele sehen in ihnen das vitale Alter Ego des Autors. Cronopien benutzen nie liniertes Papier, um zu schreiben, drücken die Zahnpastatube auch nicht von unten nach oben. Für alle Fans wurden die Cronopien zum Inbegriff Cortázars, seiner Sicht der Welt.

Er selbst ist das grösste Cronopium. Immer sah er wie ein schlaksiger Jugendlicher aus, trotz seiner Grösse (fast zwei Meter), und er schien nie zu altern. Seine blauen Augen standen weit auseinander, registrierten alles, während er bescheiden zuhörte und sein enzyklopädisches Wissen sorgfältig verbarg. Auffallend sein gutturales 'r,' ein Erbe Brüssels, wie er sagte."

142 "Y ahora paso a algo muy privado, pero que es necesario que sepas porque sobrepasa todo lo inconcebible en materia de asco. Sabés que Gallimard tiene a estudio a Rayuela. Sabés que el libro, en original a máquina, fue entregado a Roger Caillois hace un año. No sabés (pero ahora sí) que Caillois no lo leyó, por la sencilla razón de que Caillois es incapaz de leer castellano apenas escapa al rigor sintáctico de una prosa como la de Borges. Pues bien, la señora Monique Lange, encargada de las ediciones latinoamericanas, y fervorosa hasta el delirio de Les armes secrètes, acaba de decirle a una íntima amiga mía, que probablemente Gallimard no editará Rayuela porque Caillois la ha vetado.” 
from there, he obeys all the directives: they will have sent him Ghiano's review, adding that I am a dangerous Communist with sharp and bloody fingernails. And Caillois's voice is omnipotent at Gallimard, and his veto will sink the book for ever and ever. ${ }^{143}$

(Cortázar 2012b: 441)

Here we see the resonance of the outsized role that individual publishers had, as gatekeepers in Marling's sense of the word, as well as the decision-making power that they wielded in deciding what literature would enter into worldwide circulation and thus have a chance to enter into the canon of world literature. And yet three weeks later, Cortázar denied the rumor that Roger Caillois had prevented the publication of Rayuela at Gallimard. Nevertheless, Cortázar's earlier thoughts on the matter are very telling with respect to the ways in which the novel was received, in connection with reservations about Cortázar's political (re-)positioning, which was also and especially influenced by his first trip to Cuba that same year. On November 20, 1963, Cortázar relativized what he had written earlier in a new letter to Paco Porrúa:

After an informal conversation with Caillois in a hallway at Unesco, I believe that the gos-
sip was exaggerated . . .. It seems that Caillois only said that Rayuelo wouldn't fit into "La
croix du Sud," because it was too cosmopolitan in spirit, but that it would have to be pub-
lished in the collection "Du monde entier." As you can see, this completely changes
things. But that's not the end of it: two days ago, Caillois phoned me to ask me to come
see him as soon as possible, and as if he wanted to demonstrate to me his undeniable
goodwill, he told me that Claude Gallimard was wavering over whether to take the book,
but that they also did not want to lose me. What were their reasons? Four readers' re-
views, which included misgivings of various sorts, based on the typical system of presup-
posing what a novel is supposed to be and then being scandalized by the book's
"oddities."

143 “¿Ves funcionar la máquina? El primer engranaje actúa en B.A. of course, y se llama como vos quieras, grupo de Sur, gentes bien pensantes, guardianes-de-la-literatura-correcta-y-sinputeadas; se llama, sobre todo, DELENDA EST COMUNISMUS. Tu amable anécdota de hace unos meses sobre V.O. engrana minuciosamente con esta escuela. Decir Caillois es decir V.O. Desde aquí el obedece a cualquier directiva; le habrán mandado la nota de Ghiano, con el agregado de que soy un peligroso comunista de afiladas y sangrientas uñas. Y la voz de Caillois es omnipotente en Gallimard, y su veto funde el libro for ever and ever."

144 "después de una entrevista casual con Caillois en un pasillo de la Unesco, creo que los chimentos eran exagerados . . .. Parece que Caillois dijo solamente que Rayuela no podía ir en 'La croix du Sud,' porque era demasiado cosmopolita como espíritu, pero que había que publicarlo en la colección 'Du monde entier.' Como ves, eso cambia completamente la cosa. Pero eso no para ahí: hace dos días me telefoneó Caillois para que fuese a verlo lo antes posible, y como si quisiera demostrarme su innegable buena voluntad, me dijo que Claude Gallimard vacilaba en tomar el libro, a la vez que tampoco quería perderme. ¿Razones? Cuatro notas de 
On January 5, 1964, Cortázar wrote to Paco Porrúa about the negotiations between Sudamericana and Gallimard:

I think that Sudamericana needs to tell Gallimard: a) that the translation is going to present serious problems; b) that the author lives in Paris and would be willing to monitor those problems; and c) that the author believes that, in order for this not to take two or three years, the book should be translated by two people, one of whom would be in charge of the "fictional" part and the other in charge of the "Morellian" part and the texts connected with that. I think that Sudamericana should firmly insist that Gallimard connect with me to adjust those aspects; otherwise, they will give the book to some random person, who is going to misunderstand it and take four years to deliver a bad translation, and we will all be the losers. ${ }^{145}$

In December of 1965, Cortázar (2012c) reported to Porrúa that he was working with Laure Guille on the French translation, which would soon be finished (209), and on April 6, 1967, he wrote to him about the early stages of the reception in France: "As for Marelle, I want you to know that after two idiotic reviews, something reasonably good just came out in Le Monde" (En cuanto a Marelle, quiero que sepas que después de dos reseñas idiotas, acaba de salir algo bastante bueno en Le Monde; 400). Today, although it never achieved comparable international sales successes, Cortázar's Rayuela ranks along with García Márquez’s Cien años de soledad as one of the best-known 20th-century novels by a Latin American writer. The text was a real hit with the French reading public in the late 1960s and became a cult book, beginning in Paris, for an entire generation of intellectuals.

\section{IV.3.5 Third Phase of Reception: The United States}

The book's translation history in the United States, like that in France, is marked by Cortázar's intense involvement in relationships with publishers and

\footnotetext{
lectura, en las que había reparos de diversa índole, basadas en el sistema típico de presuponer lo que debe ser una novela, y escandalizarse después por las 'rarezas' del libro."

145 "Creo que Sudamericana debe indicarle a Gallimard: a) que la traducción va a plantear serios problemas; b) que el autor vive en París y estaría dispuesto a supervisar los problemas que eso plantee; c) que el autor cree que, a fin de que no pasen dos o tres años, convendría que el libro fuese traducido por dos personas, una de las cuales se haría cargo de la parte 'novelesca,' y la otra de la 'morelliana' y textos conexos. Creo que Sudamericana debe pedirle redondamente a Gallimard que se conecte conmigo para ajustar esos aspectos; de lo contrario, le darán el libro a cualquier señor que lo entenderá mal, y tardará cuatro años en entregar una mala traducción, con lo cual saldremos perdiendo todos."
} 
translators. In his study of author-publisher relationships, José Luis de Diego writes about Cortázar:

Over and over, as we can see, Cortázar defended the contacts that he had created with publishers and translators, and that double agency in the business dealings often resulted in conflicts with Sudamericana. But, beyond those conflicts, it is clear that Cortázar chose well: Pantheon Books, Gallimard, Einaudi, Suhrkamp. ${ }^{146}$

(2015: 177)

In 1959 and 1960, Cortázar wrote first to his French translator, and next to his then-translator in the United States, Paul Blackburn, who was also acting as his agent, to say that he had excluded their respective working relationships when his Argentine publisher offered to represent his interests on the international book market. At the beginning of 1960, he wrote to Blackburn:

By the way, my publisher in Argentina offered to become my literary agent worldwide. I said yes, with the exception of the United States, and I gave them your name so that they know that you are my agent there. (I'll give you a piece of information, I mean I'll give you a hint: my publishers told me that Knopf is looking for Argentine writers who would be worth their time. Don't you think that Las armas secretas might interest them? $)^{147}$

(2012b: 213)

Even in the United States, it was not easy to find a publisher for a volume of short stories, although it was Las armas secretas that Cortázar, rightly, wanted to get published in English more urgently than, say, Los premios. And yet it was Los premios, which was first published by Sudamericana in 1961 and already appeared in its French translation in 1961, that was Cortázar's first work to be published in English in its entirety. The Winners came out in the United States in March of 1965, in the translation by Elaine Kerrigan. The novel received a number of reviews, both good and bad; its reception was apparently mostly filtered through its ability to connect to motifs within the European and North American tradition. Los premios enters into a tradition of fantastical literature (in the footsteps of Jorge Luis Borges), and Cortázar also takes up mythical traditions from world literature. Using the motif of navigation and ship travel,

146 "Como se ve, Cortázar defendió, una y otra vez, los contactos que fue creando con editores y traductores y a menudo esa doble agencia de los negocios trajo conflictos con Sudamericana. Pero, más allá de esos conflictos, es evidente que Cortázar elegía bien: Pantheon Books, Gallimard, Einaudi, Suhrkamp.”

147 "By the way, mi editor en la Argentina se ofreció para convertirse en mi agente literario en el mundo entero. Acepté, con la excepción de los Estados Unidos, y les di tu nombre para que sepan que eres mi agente allá. (Te paso un dato, I mean I'll give you a hint: mis editores me dijeron que Knopf andaba buscando autores argentinos que valieran la pena. ¿No crees que Las armas secretas les interesarían?)" 
which is also very present in contemporary literature, Los premios was able to be compared, for instance, with Sutton Vane's Outward Bound (which Los premios explicitly alludes to [Cortázar 1965: 116]) and Katherine Anne Porter's Ship of Fools - two works that were well-known and very present to readers in the United States (Chapman 1985: 20-22).

In spite of the existing translations into French (including Les gagnants, 1961), Cortázar had been largely ignored by literary critics in the United States, who therefore did not take into account the fact that in addition to Los premios he had also published a play (Los reyes, 1949) as well as three short story collections - Bestiario (1951), Las armas secretas (1959), and Historias de cronopios y de famas (1962) and that he had a second novel out, namely Rayuela (1963). But this relative ignorance from the United States also gave him the advantage of being treated with the same curiosity as a debut author would have been (Chapman 1985: 19).

Cortázar also benefited from the fact that in the winter and spring of 1965 , Los premios was extremely socially relevant in the United States. Given the civil rights marches and boycotts, the student uprisings, the emerging conflict in Vietnam, and the assassination of John F. Kennedy, many US citizens viewed their government skeptically and were afraid they were being manipulated or even brazenly lied to by it - something that was thematized and reflected in Los premios (20).

In the US book market, which was saturated with European books and movies, an author from Argentina was a welcome change, which increased the curiosity about Cortázar's work. At the same time, the way had been paved for him to some degree by earlier translations of Argentine works: Black Valley (1928), Stone Desert (1928), and Peach Blossom (1929) by Hugo Wast; Nacha Regules (1922) and Holy Wednesday (1934) by Manuel Gálvez; and Fiesta in November (1942) and The Bay of Silence (1944) by Eduardo Mallea. But of particular importance was the fact that Jorge Luis Borges was Cortázar's immediate predecessor in the chronology of publishing. Borges's Fictions and Labyrinths appeared only two years and Dreamtigers only one year before The Winners (Chapman 1985: 22).

The quality of the translation also played an important role in the reception of the book. Although Arnold Chapman criticizes a few of the idiomatic expressions, he is nevertheless convinced that after a new revision, The Winners "could stand among the best translations of Spanish American fiction" (36). The Winners received a broad-based response, with the first preliminary review, on January 15, 1965, in Kirkus Service, describing it as having "the suspense and serial ruminations of a top-rate philosophical creepy.” The New York Times gave the book both its best (William Goyen) and worst (Orville Prescott) reviews. The rest of the reviews were situated somewhere between these two extremes (Chapman 1985: 23-26). In spite of the diversity of the reviews, they all contributed, 
taken together, to Cortázar's becoming a deservedly established and recognized writer around the world, as Chapman summarizes it (36).

In a letter dated November 11, 1963, Cortázar wrote to Paul Blackburn about inquiries from the United States about the rights to Rayuela: “A Mrs. Cornelia Schaeffer, from Atheneum, has been chasing me all around Europe. The poor soul thought I was the master of my fate and even the pilot of my soul concerning copyright in the USA . . .. She seems to be awfully interested in Rayuela" (2012b: 447). He reminded Blackburn that Pantheon Books had priority in acquiring the rights. The letters also provide insight into Cortázar's collaboration with Gregory Rabassa, who translated the novel for Pantheon Books, where it was first published in English, in 1966. Rabassa, as is well-known, won the US National Book Award for Translation for his translation of Hopscotch. ${ }^{148}$ He also later translated Libro de Manuel (A Manual for Manuel, 1978) and 62 Modelo para Armar (62: A Model Kit, 1972).

Commenting on the translation process for Hopscotch, Cortázar wrote to Rabassa on March 15, 1965 that he continued to be very satisfied with Rabassa's work: "I still find it splendid," "so intelligent and so sensitive" (me sigue pareciendo espléndido; tan inteligente y tan sensible). He confessed that "Sometimes I am afraid to seem silly or pedantic to you, but I hope that taken together, my observations can be helpful to you" ( $A$ veces temo parecerte tonto o pedante, pero creo que en conjunto mis observaciones pueden ayudarte; 2012c: 48). He continued with an example: "In this case, and because chapter 36 is fundamental for me, I have insisted that you examine a few things. I think that you have gotten the tone perfectly, but because there are difficult passages, it was natural that in some cases you would make mistakes; I think that in each case, there are easy fixes" (En este caso, y dado que el capítulo 36 es fundamental para mí, he insistido que examines unas cuantas cosas. Creo que has conseguido perfectamente el tono, pero como hay pasajes difíciles, era natural que en algunos casos te equivocaras; creo que todo tiene fácil remedio; 48-49). On July 18, 1976, when he sent Rabassa back the final corrections, Cortázar also included, yet again, reflections on their work process, and expressed his thanks:

In every letter I have written to you when returning pages to you, I have told you how grateful and appreciative I was for your work. Now that it is finished . . . I must tell you again how much it has meant to me to find a translator - who has also become a great friend - in whom I could have complete confidence. ${ }^{149}$

148 https://www.nationalbook.org/books/julio-cortazars-hopscotch/.

149 "En cada carta que te he ido escribiendo cuando te devolvía las páginas, te he dicho cuánto apreciaba y agradecía tu trabajo. Ahora que está terminado . . . necesito repetirte lo 
After this laborious, meticulous translation and reviewing process was finished and the book had been published, the publisher sent Cortázar a series of reviews in English, "some of them very good and intelligent, the rest of them as idiotic as expected. But, as always in the USA, even the most intelligent of them do not understand the book's metaphysical quest; they see it, praise it, and extol it as a novel, and nothing more than that. Finally, and it's a lot" (algunas muy buenas e inteligentes, las otras esperablemente idiotas. Pero como siempre en los USA, ni siquiera los más inteligentes intuyen la búsqueda metafísica del libro; lo ven y lo elogian y lo exaltan como novela, nada más. En fin, y es mucho; 280). Writing to Rabassa on July 30, 1966, he commented on the negative reviews of Hopscotch and made a key observation about the reception among critics in the United States:

All of the many reviews of Hopscotch have one thing in common: that the reviewer was wrong and, like the one from Time Magazine, believed that you have to read the book twice. And it seems like my theory about female readers - remember? - is truer than it seemed. If a literary critic makes this kind of mistake from the beginning, what can we expect of the common reader? ${ }^{150}$

There is, however, also a suspicion that arises here that some of the literary critics who followed were taking their cue as much from the reviews that had already appeared as from their own reading of the book - it would certainly be instructive to check whether a careful comparison of the various reviews confirmed this suspicion. Cortázar went on:

I have to laugh at the frequency of these mistakes: at least 15 of the reviews start from this false assumption, and of course they found the book unbearable. I would feel that way too if I had to read it two times in a row but in a different order . . .. I am sorry that Hopscotch did not meet with a better reception, and you must believe that I mean it very seriously when I tell you that I am much sorrier on the Blackburns' behalf than on my own . . .. But there is something in this book that does not coincide with the Weltanschauung of American intellectuals; its metaphysics bothers them, and they see my technical experiments, which are more serious than they assume, as exhibitionism. ${ }^{151}$

(ibid.)

mucho que ha significado para mí encontrar a un traductor - que además se ha vuelto un gran amigo - en el que yo podía tener una total confianza."

150 "Las muchísimas críticas de Hopscotch coinciden todas en una cosa: en que el reviewer se equivocó y creyó, como el de Time Magazine, que había que leer dos veces el libro. O sea que mi teoría sobre los lectores-hembra, ¿te acuerdas?, es más verdadera de lo que parece. Si un señor crítico se equivoca de entrada en esa forma, ¿qué se puede esperar del common reader?" 151 "Me da risa la frecuencia de esas equivocaciones; por lo menos 15 críticas parten de esa base falsa, y naturalmente el libro les pareció insoportable. A mí también me lo parecería si tuviese que leerlo dos veces seguidas, aunque fuera en un orden diferente . . .. Lamento que Hopscotch no haya tenido mejor acogida, y puedes creer que soy muy sincero si te digo que lo 
It is indeed very telling that the novel was so fundamentally misunderstood in this way, and that its formally innovative character was not understood, in the United States, of all places. From Cortázar's perspective, there was also something more about the "worldview" of the reviewers in the US that was a bad fit with his literature: he did not meet the expectations of North American literary critics for a Latin American writer. Cortázar continued:

It bothers the American critics that an Argentine or a Mexican would have a universal, European spirit instead of writing about little ranches, capitulin, tequila, or sad cowboys; there are several of them who imply that. In other words, an Argentine has no right to be cosmopolitan. But what would Hemingway, Scott Fitzgerald, Gertrude Stein, or so many other Americans have done without the great European experience? It hasn't occurred to them to think about that when they accuse me of being a playboy of Frenchified literature. Anyway, let them go to hell, they're not who I'm writing for. ${ }^{152}$

(ibid.)

For a long time, Cortázar felt unappreciated in the United States, and misunderstood as precisely this "playboy of Frenchified literature." He wrote something similar to Eduardo Jonquières in a letter dated August 3, 1966:

By the way, I have read a lot of good studies of Rayuela over the last few months; in the United States, they have almost never understood the intention of the book and they accuse me of being a "Europeanizer." Subconsciously, the Yankees only want Argentines or Chileans to write novels with gauchos, mate, and sweet señoritas. As soon as we start to open the lens a little wider, they criticize us . . .. It's all very well, but I don't see why the masters from New York have to require localism in order to approve of what we do. ${ }^{153}$

$(320-21)$

lamento por los Blackburn mucho más que por mí . . .. Pero hay algo en ese libro que no coincide con la weltanschauung de los intelectuales americanos; les molesta su metafísica, y toman por exhibicionismo mis experiencias técnicas que son más serias de lo que suponen.”

152 "A los críticos americanos les molesta que un argentino o un mexicano tenga espíritu universal, europeo, en vez de escribir sobre ranchitos, capitulín, tequila o gauchos tristes; hay varios que lo dan a entender claramente. $O$ sea que un argentino no tiene derecho a ser cosmopolita. ¿Pero qué hubieran dado Hemingway, Scott Fitzgerald, Gertrude Stein, tantos otros americanos, sin la gran experiencia europea? No se les ha ocurrido pensarlo cuando me acusan de ser un playboy de la literatura afrancesada. En fin, que se vayan al carajo, no es para ellos que yo escribo."

153 "Por cierto en estos meses he leído cantidad de buenos estudios sobre Rayuela; en los USA no han entendido casi nunca la intención del libro, y me acusan de 'europeizante.' Subconscientemente, los yanquis quisieran que un argentino o un chileno sólo hicieran novelas con gauchos y mate y sweet señoritas. Apenas abrimos el diafragma, nos censuran . . .. Está muy bien, pero no veo por qué los dómines neoyorkinos tienen que exigirnos localismo para encontrar bien lo que hacemos." 
The reactions to the British English edition, which was published in London in 1967, were remarkable. On March 6, 1967, Cortázar reported to Paul Blackburn that the British edition of Hopscotch had come out that week: "I had two reviews, one from The Sunday Observer, quite lousy (the fellow didn't read the book) and one from The Sunday Times, which I liked a lot” (382). Elsewhere, he wrote: "But I read the reviews: the one by Raphael is decent, even though he doesn't like the book .... The one in the Observer is a lousy mess" (Pero leo las reseñas: la de Raphael es digna aunque no le guste el libro . . .. La del Observer es una cochina; 384).

Overall, Cortázar came to the following conclusion (as he wrote in a letter to Sara and Paul Blackburn, dated May 11, 1967): "Did I tell you that the critical reception of Hopscotch in England has been more brilliant than in North America? There were fewer mistakes, and in general, the critics were better at perceiving some of the novel's intentions" ( $¿$ Te dije que la critica inglesa de Hopscotch ha sido más brillante que la norteamericana? Hubo menos equivocaciones, y en general los críticos percibieron mejor algunas de las intenciones de la novela; 424). A critical analysis of the reviews and of Cortázar's assessments of the same would surely be helpful, even with the time that has since elapsed, in order to analyze these relationships in detail. But regardless, Cortázar's perception, as expressed in his Letters, once again underscores the fact that his literature was able to connect in Europe but that in the US, which was so important to the international circulation of his work, there were definite difficulties at first in terms of how literary critics received and transmitted his work. In writing to Paul Blackburn - and this is also very revealing for an understanding of some of the circumstances of those years - Cortázar summarized what he saw as the challenges of what had been required of him in the now-finished phase of intensive work on the text of Rayuela in various translations:

It took me four years to write Rayuela; then there followed a year of managing and reviewing the American version; then, as soon as that was done, I had to deal with the task of taking care of the French version, which has now just come out in Paris. And then, when I thought I was only going to receive a review or commentary every now and then, I found myself dealing with the beginning of the Italian version, which represented another year of consultations, letters back and forth, please tell me how to say "idiotic shit” in Italian, etcetera. Luckily, I'm running out of known languages here. ${ }^{154}$

(384)

154 "Cuatro años me llevó escribir Rayuela; luego empezó un año de control y revisión de la versión americana; apenas terminada, me cayó encima la tarea de cuidar la versión francesa, que acaba de salir en Paris. Y cuando sólo creía recibir de cuando en cuando alguna reseña o comentario, se me aparece el comienzo de la versión italiana, que representará otro año de 
It has become very clear that Cortázar devoted himself intensely to collaborating with the translators in all of the languages that he spoke and, in addition, that he studied all of the reviews that appeared of his publications, including the translations. José Luis de Diego pointed out something crucial in this regard: He writes that Cortázar focused on the two aspects of translations and reviews in his behavior with respect to the book market, but that otherwise, he always dodged his publishers when it was a matter of advertising his books, of interviews, readings, etc. He also harbored a negative image of various publishers; given that, his relationship with Porrúa at Sudamericana - especially from 1959 to 1968 - which had grown positive and trusting, was an exception. De Diego writes: "We can affirm that the relationship with Porrúa ushered in Cortázar's successful period, beginning with the 1959 publication of Las armas secretas. However, his work as a publisher on Cortázar's work began in 1960, with the publication of Los premios" (Se puede afirmar que la relación con Porrúa inauguró el período exitoso de Cortázar, a partir de la publicación, en 1959, de Las armas secretas. No obstante, su labor como editor, en relación con la obra de Cortázar, comenzó en 1960, con la publicación de Los premios; 2015: 171). De Diego calls the years from 1959 to 1968 the "Porrúa period" (175); at the same time, however, "If we extend our gaze a little bit . . . we will notice that the successful writer appears to stubbornly turn his back on the market" (Si extendemos un poco la mirada . . . advertimos que el escritor de éxito parece ponerse obstinadamente de espaldas al mercado; ibid.). De Diego justifies this, on the one hand, with evidence that Cortázar refused to take part in literary contests (he did not want to submit to Emecé or Kraft, for instance). On the other hand, he writes, Cortázar also frequently refused interviews and promotional events. Porrúa once suggested that he give an interview to the weekly Primera Plane, because they so generously advertised his books. He finally agreed to the interview, as an exception, but then he again refused to sit on the jury of a literary prize that the newspaper awarded - according to de Diego, he didn't want to be part of that kind of give and take (cf. ibid.). De Diego concludes that:

This attitude seems to contradict the generalization that some critics, including Ángel Rama and David Viñas, have made regarding the exposure of the Boom authors to the rules of the market, a phenomenon that is visible with writers such as Mario Vargas Llosa and Carlos Fuentes, but not with Cortázar, or at least not in what we have called the

consultas, carta va y carta viene, la prego di spiegarme come si dice 'turro de mierda' in italiano, etc. Menos mal que aquí se me acaban los idiomas conocidos.” 
"Porrúa period.” And yet while, on the one hand, he rejected what we usually call the mechanisms of consecration, there are two aspects connected with the market that constantly mobilized his attention. ${ }^{155}$

These aspects are the two we have already named, namely Cortázar's work on translations and response to reviews.

\section{IV.3.6 Further Contexts of Reception in Europe}

\section{Italy}

While Cortázar, who at that point was already an internationally famous author, had difficulty getting his short story collections published in France and the United States at first, in Italy it was precisely his short stories that were received and promoted. Here, again, some individual letters are revealing. On May 19, 1962, for instance, Cortázar wrote to Porrúa to say that he was finished with Rayuela and with the new edition of Final del juego (with nine new stories). He complained that he had not yet received any copies of Cronopios. He also mentioned that Einaudi wanted the book: "I haven't received the cronopios . . .. I would so like to see how the little book turned out. Did you know that Einaudi is desperately asking for it? Also send me a copy that I can send to them from here" (No he recibido los cronopios .... Quisiera tanto ver cómo quedó el librito. ¿Sabés que Einaudi lo reclama furiosamente? Mándame también un ejemplar para que yo se lo haga llegar desde aquí; Cortázar 2012b: 275).

The first Cortázar volume to appear in Italy was Le armi segrette, which was published by Rizzoli in 1963. Cortázar gained access to Einaudi a little later through Italo Calvino. According to de Diego's description (2015: 178), a special arrangement was reached: in return for Einaudi publishing Cortázar, Minotauro, the publishing house that Porrúa had founded in 1955, published three volumes by Italo Calvino: Le cosmicomiche (Cosmicomics), Ti con zero ( $t$ zero), and Le città invisibili (Invisible Cities).

On February 13, 1964, Cortázar wrote to Paco Porrúa that he had just received part of the Italian manuscript of Los premios and that he thought the translation

155 "Esta actitud parece contradecir la generalización que algunos críticos, como Ángel Rama y David Viñas, han realizado con respecto a la exposición de los autores del boom a las reglas del mercado, fenómeno que es visible en autores como Mario Vargas Llosa y Carlos Fuentes, pero no en Cortázar, al menos en lo que hemos llamado el 'período Porrúa.' Pero sí, por un lado, rechazaba lo que solemos llamar mecanismos de consagración, hay dos aspectos relacionados con el mercado que movilizaron constantemente su atención.” 
was very well done (2012b: 491). In the fall of that year, on October 26, 1964, Cortázar asked Porrúa for written permission for Einaudi to publish all of his stories in one volume in Italy. In that letter, Cortázar also referred to Italo Calvino's role as a mediator:

For a long time now, Einaudi (through Italo Calvino, who has become a fan of my stories) has been talking about putting together one single volume with all of my published stories. It appears that they made up their minds a month ago, and have entrusted the preparation of the volume to a young woman who has already translated Los premios (which will have to wait in line at Einaudi because, unusually for a publisher, they would rather release the stories first). ${ }^{156}$

(2012b: 589)

Il gioco del mondo (Rayuela) appeared in 1969; for this volume, too, Cortázar collaborated with the translator, Flaviarosa Nicoletti Rossini.

\section{Germany}

Cortázar had contacts in Germany beginning early on, even though he himself did not speak German. He mentioned these contacts, among other things, when he was working towards getting his short stories published in Argentina, in the late 1950s. At the end of a letter to Eduardo Jonquières dated January 15, 1958, Cortázar addressed María Rocchi (Jonquière's wife) and wrote about his attempts to get El examen and various stories published in Argentina. In the process, he briefly mentioned that "La noche boca arriba" had been published in a magazine in Berlin and, apparently, also read on a radio show:

The people at Sur did not take El examen, because Victoria [Ocampo] wrote to me in Paris to say that the quota for 1958 had been met and even exceeded. I still don't know whether Sudamericana is going to accept the four stories that I left with them; I am going on with my novel [Los premios], which I have told Eduardo something about, and I have just received a beautiful German magazine, published in Berlin, which includes the translation of one of my stories, "La noche boca arriba." Apparently it was read on the radio and left the "boches" [French insult for Germans] staring at the ceiling. As a Creole nationalist would say, it's time those gringos found out who we Argentines are . . . ${ }^{157}$

(2012b: 147)

156 "Hace ya tiempo que Einaudi (por vía de Italo Calvino, que se ha vuelto un entusiasta de mis cuentos) está hablando de hacer un volumen único con todos mis cuentos publicados. Parece que hace un mes se decidieron, y le confiaron el montaje de la edición a una muchacha que ya tradujo Los premios (que deberá esperar turno en Einaudi porque, cosa rara en un editor, prefieren lanzar primero los cuentos)."

157 "Los de Sur no me aceptaron El examen, pues Victoria me escribió a París diciéndome que la cuota para 1958 estaba cubierta e incluso superada. Todavía no sé si Sudamericana aceptará los cuatro cuentos que le dejé; yo sigo con mi novela, de la que algo le digo a Eduardo, y acabo de recibir una preciosa revista alemana, editada en Berlín, donde figura la traducción de uno 
In a letter dated February 15, 1958, Cortázar wrote to Jean Barnabé that his Historias de cronopios y de famas had also been read on the radio:

My Historias de cronopios y de famas - which I don't think you know - were read on the radio in German yesterday, in Saarbrücken. I wonder how the audience reacted . . .. Apparently, I have success in Germany. A luxurious magazine in Berlin has published 'La noche boca arriba,' and they are talking to me about a possible edition in Zurich. That would be fun. ${ }^{158}$

(2012b: 149)

The force behind this German success was the translator Edith Aron, who was one of the crucial figures for the early mediation of Cortázar in Germany, according to Katharina Einert. ${ }^{159}$ Cortázar wrote to Paul Blackburn on March 27, 1959, to give him permission to publish his Historias de cronopios y de famas in New Directions in Poetry and Prose, no. 17 (1961), and in that letter he also mentioned Edith Aron, with whom he had had an affair in the early 1950s, as becomes clear from the letters, and with whom he then remained friendly: "Before I left Paris I saw Edith, who is doing very well. She is going to have my stories published by the Insel Verlag. How strange to find oneself translated into German! But people like my things in Germany; it must be because of a greatgrandmother from Hamburg who is in my blood" (Antes de salir de París la vi a Edith, que está muy bien. Me va a hacer publicar los cuentos en la Insel-Verlag. ¡Qué raro verse traducido al alemán! Pero mis cosas gustan en Alemania, debe ser por una bisabuela de Hamburgo que llevo en la sangre; 2012b: 183).

Luchterhand was the first German publisher to bring out Cortázar's stories and his novel Los premios (as Die Gewinner), in Edith Aron's translation. Beginning on September 2, 1964, his letters started to discuss problems between Aron and Cortázar's German publisher, the Luchterhand Verlag (573-74). Essentially, the dispute had to do with the publisher's dissatisfaction with Aron's translation of Los premios as well as with her unreliability in the working process (Einert 2018: 178-184). At Suhrkamp, which started becoming interested in Cortázar in the 1970s, there was no longer any discussion about working with Aron (190).

de mis cuentos, 'La noche boca arriba.' Parece que fue leído por radio y los dejó a los 'boches' mirando p'al techo. Como diría un nacionalista criollo, ya es tiempo que sepan esos gringos quiénes somos los argentinos..."

158 "Mis Historias de cronopios y de famas - que creo que ustedes no conocen - fueron leídas ayer en alemán por la radio de Sarrebrück. Me pregunto cómo habrá reaccionado el público . . . Parece que tengo éxito en Alemania. Una lujosa revista de Berlín ha publicado 'La noche boca arriba,' y me hablan de una posible edición, en Zürich. Sería divertido.”

159 On this subject in more detail, see Katharina Einert's dissertation, Die Übersetzung eines Kontinents (The translation of a continent), especially her chapter on Julio Cortázar and his translations in West Germany (Einert 2018: 159-216). 
In Germany, as elsewhere, Cortázar did not have any kind of quick success; instead, some of his volumes became long sellers over the years. In France, Rayuela had become a cult book for the intellectual avant garde, and of course that did not go unnoticed in Germany. Nevertheless, it took 18 years before the original edition of 1963 was finally able to appear in translation. In 1980, after years of waiting for the translation by Fritz Rudolf Fries, the book was finally supposed to appear at Suhrkamp. Unseld had just released the manuscript for printing when he read a scathing review of another newly released Borges book in Germany, which had been translated by Curt Meyer-Clason, one of the few other renowned translators of Latin American literature in Germany. The review so alarmed him that he gave the galley proofs of the Fries translation to his editor for Latin American literature, Wolfgang Eitel, to inspect again. After a three-week -long examination by Eitel and a consultation among Unseld, Eitel, Michi Strausfeld (Suhrkamp's agent for Latin America), and Elisabeth Borchers, a very experienced editor, the Carpentier translator Anneliese Botond was commissioned to reexamine the Rayuela galley proofs. This process is documented in the Siegfried Unseld Archive at the German Literature Archive in Marbach; it was surely one of the most complex translation processes in the entire history of the publishing house (see Einert 2018: 199-205). In August, 1980, Unseld wrote to Cortázar:

I have now spoken with Ms. Botond, and her conclusions are pretty devastating for us. Apparently, the level and the tone of Fries's rendering aren't bad, but the translation is variable, sometimes brilliant and sometimes clumsy (she suspects what two other people had suspected before her, that a preliminary translator or a second translator may have been helping Fritz Rudolf Fries). But even if we accept the variability, the translation is just impossible because of all of the errors that would have to be corrected. ${ }^{160}$

(Letter from S. Unseld to J. Cortázar, 08/27/1980, SUA)

Unseld then commissioned Anneliese Botond to revise the entire translation one more time. The German version, which unlike the French, English, or Italian ones was created without Cortázar's collaboration, thus required multiple revisions before it could finally appear. Overall, the history of Cortázar translations in Germany underscores the complexity of the task, although in this particular case several unfortunate circumstances certainly contributed to the fact

160 "Inzwischen habe ich mit Frau Botond gesprochen, ihr Resultat ist für uns ziemlich niederschmetternd. Das Niveau und der Ton der Übertragung von Fries seien nicht schlecht, aber die Übersetzung sei unterschiedlich, mal glänzend, mal holprig (sie vermutet, was vor ihr schon zwei andere Personen vermutet haben, dass vielleicht ein Vor-Übersetzer oder ein zweiter Übersetzer Fritz Rudolf Fries zur Seite gestanden haben). Aber selbst, wenn man diese Unterschiedlichkeiten hinnähme, unmöglich sei die Übersetzung wegen der Fehler, die korrigiert werden müßten.” 
that it took such a long time for Rayuela to reach the German-speaking reading public.

\section{The Netherlands}

In terms of the reception in the Netherlands of Latin American literatures as a whole, Rowan van Meurs has pointed out that until 1967, Spanish literature was more popular than Latin American literature, although García Márquez’s Cien años de soledad (which first appeared in 1967), in particular, contributed to the reversal of this trend (van Meurs 2014: 28-29). De Mierenmoordenaar (Historias de cronopios y de famas) was the first Dutch translation of one of Cortázar's works, and also appeared in 1967. From that point on, more and more Latin American literature was translated, published, and reviewed (van Meurs 2014: 19-20). Between 1946 and 1985, Cortázar, with 16 translations of his work, was the third most popular Latin American writer in the Netherlands, according to van Meurs (29); the first two were García Márquez (with 18 translations) and Neruda (with 17).

The Meulenhoff press, in particular, devoted itself to the publication of Latin American works. Cortázar became one of Meulenhoff's regular authors after the first three translations went into reprints (van Meurs 2014: 35-36). Beginning in 1972, Barber van de Pol was the main translator of his works (van Meurs 2014: 36), and in 1975 she was awarded the Martinus Nijhoff Prize for her translation of Rayuela. Of the 41 reviews listed by van Meurs that appeared in the Netherlands of Cortázar's books, 13 of them were entirely positive, 13 mostly positive, and 3 mostly negative, while 12 reviews contained no clear judgment; none of them categorized the work under review as entirely negative (2014: 46). The Netherlands was among the countries of Europe in which Cortázar was published and read over the course of many years, very clearly also in the context of a growing interest in Latin American literature overall.

\section{Spain}

At this point, at the very latest, the question arises of why Cortázar was not canonized by way of Barcelona. After all, that was the first phase of the reception of so many other Latin American writers of that time. The first title of Cortázar's to appear in Spain was Ceremonias, in 1968, which brought together stories from Final del juego and Las armas secretas. More publications followed in the 1970s. But why so late? That is a question that José Luis de Diego asks (2015: 179), reporting that of course Cortázar also grappled with this question, and repeatedly asked Porrúa what was going on with Spain. Carlos Barral was interested in publishing Cortázar and tried to negotiate directly with the author, but Cortázar 
pushed for the matter to be arranged in agreement with Sudamericana, his Argentine publisher. And Sudamericana apparently preferred either to publish Cortázar through Edhasa, their own branch in Spain, or else to arrange an exchange, whereby Sudamericana authorized Seix Barral to publish Cortázar and in return, Seix Barral gave Sudamericana the rights to publish Vargas Llosa, who was under contract with Seix Barral, in Argentina. In December of 1966, Cortázar wrote to Porrúa at Sudamericana:

Don Carlos [Barral] has maintained his impenetrable silence that I told you about. As far as I'm concerned, he can go to hell, I am already completely fed up with this business with Spain, but the bad part is that I keep getting requests from there, and it really is a shame that because of the Old Man's intervention, or whatever it is, there is an impasse where something should have happened a long, long time ago. It seems absolutely nuts to me that I am being published in Bratislava but not in Barcelona. ${ }^{161}$

(quoted in de Diego 2015: 180)

De Diego quotes from Barral's journals to show that although he did want Cortázar on his publishing list (he worked on making that happen from 1964 to 1967), Barral did not personally appreciate Cortázar’s literature:

After a quick, cold supper, I returned to the table, I kept reading (still that big old novel by Cortázar), and I proofread Metropolitano without much conviction. During the day, like last night, I scribbled a few pages, but I didn't have much fun. Both that boring book of Cortázar's (I shouldn't have brought that book home) and the dog, whose needs I have not yet been able to find room for in my project, in the sluggish distribution of my time, have kept me from any noticeable efforts of concentration. ${ }^{162}$

(Barral 1993: 119, quoted in Diego 2015: 180-81)

161 "Don Carlos se mantuvo impenetrablemente silencioso desde lo que te conté. Por mí se puede ir al carajo, esta historia con España ya me tiene harto, pero lo malo es que continuamente me llegan pedidos desde allá, y finalmente es una lástima que por la intervención del Old Man o lo que sea, haya un impasse en algo que hace ya mucho, pero mucho, que tendría que estar hecho. Que me editen en Bratislava y no en Barcelona me parece demencial.”

162 “Tras una cena fría y rápida he vuelto a la mesa, he leído de nuevo (siempre ese novelón de Cortázar) y hecho sin mucha convicción una lectura de correcciones de Metropolitano. Durante el día, como anoche, he garabateado algunas cuartillas, sin divertirme demasiado. Tanto ese pelma de Cortázar (no debía haber traído ese libro) como el perro, cuyas necesidades no he acabado de ubicar en mi proyecto, en mi perezosa distribución del tiempo, me han impedido esfuerzos de concentración notables." 


\section{IV.3.7 Political Activism and World Literary Reception}

I do not want to close this chapter without returning to the role that Cortázar's political activism played in the reception of his work in a world literary context - although the controversies over Cortázar's political activism can certainly not be dealt with in their entirety here. As Standish (2001) writes, political issues significantly increased Cortázar's visibility, but on the other hand, they also massively limited his reception: many intellectuals found Cortázar's positions, especially with respect to the revolutions in Nicaragua and Cuba, untenable, and he was strongly attacked. In his relationship with the French publisher Roger Caillois, we can see some of the distance that people in parts of the literary business maintained from a "Communist" like Cortázar. As Mario Benedetti writes:

If he had yielded to pressure and joined the chorus of the detractors of Cuba and Nicaragua, two revolutions that he knew from up close and that he always defended, the biographies drawn up on the occasion of his death would certainly have included a whole list of top-notch international prizes. But Cortázar is leaving without any awards, at least in the Spanish-speaking world (the French did give a prize to the Libro de Manuel). ${ }^{163}$ (2014: 272)

It is remarkable, and certainly not due to the literary quality of his various texts, that Cortázar won an award for Libro de Manuel but not, during his lifetime, for any other of his writings (the only other literary prize he won was the Konex Award for Excellence in the category of Letters in 1984, the year of his death).

In terms of his political activism, Cortázar's life can be divided into two parts (see Standish 1997). For the first forty years of his life, which he spent in Argentina, he himself said that he was "emphatically indifferent to the political situation" (acentuadamente indiferente a las coyunturas politicas). Although he felt "anti-Peron, he had never joined any political groups that could have led to any kind of political anti-Peronist activity" (antiperonista pero nunca [se integró] a grupos políticos . . . que pudieran tratar de llegar a hacer una especie de práctica del antiperonismo; see Prego 1985: 127-30, cited in Standish 1997: 466). At that time, his focus was on the aesthetics of literature, and he was willing to "sacrifice human values for the sake of formal perfection in his stories" (sacrificar un poco

163 "Si hubiera cedido a las presiones y se hubiera sumado al coro de detractores de Cuba y Nicaragua, dos revoluciones que conocía de cerca y que siempre defendió, las fichas biográficas pergeñadas con motivo de su muerte habrían incluido seguramente toda una nómina de premios internacionales de primer rango. Pero Cortázar se va sin premios, al menos en el área hispánica (los franceses galardonaron el Libro de Manuel).” 
de valor humano en aras de una perfección formal). Nevertheless, there are stories in Bestiario (1951) and Final del juego (1956) that include political allegories. "Casa tomada," for instance, alludes to the decadence of a calcified bourgeois order, while "Las Ménades" contains a warning against the dangers of national gullibility, political fanaticism, and the inaction of those who know enough to keep a certain distance from social events (Standish 1997: 466).

Cortázar's attitude changed when he moved to Paris in the early 1950s, beginning his voluntary exile. The Cuban Revolution, along with a chain of other events, including the Vietnam War and economic crises, caused him to become politically active. He found something "cathartic" in his first trip to Cuba, in 1963, and in 1964, he published Reunión, one of his realistic stories, which is written from the point of view of Che Guevara and includes the protagonists Luis and Pablo, who are veiled versions of Fidel and Raúl Castro. Cortázar increasingly spoke out on political issues, took part in the Russell Tribunal on human rights, declared his opposition to the military dictatorships in Argentina and Chile, and supported the Sandinistas in Nicaragua (Standish 1997: 466). At the same time, Cortázar continued to publish stories that had no political undertones, and in the late 1970s, he found himself once again in debates, with Mario Vargas Llosa among others, over the role and responsibility of Latin American intellectuals. Cortázar defended the opinion that literature should not be subordinated to a particular purpose, that the author should always be free to write about whatever came to his mind ("he found intellectual dictatorship to be no less intolerable than the political kind" [la dictadura intelectual no le resultaba menos intolerable que la politica; Standish 1997: 470]). As a result, he was strongly criticized by the militant left (467-69).

Libro de Manuel appeared in 1973 and was Cortázar's fourth novel and his most controversially discussed; it angered people on both the political right and the political left. While rightists accused him of betraying his bourgeois roots, leftists objected to his intellectualism and demanded that he write more colloquially. Outside of Latin America, the book was received more positively, but modestly. In France, however, as mentioned above, it won an important prize:

The fire of controversy surrounding Libro de Manuel was rekindled in 1974, when it won the Prix Médicis, awarded annually in France for the best foreign novel. In a symbolic and very public gesture, Cortázar donated the prize money to the Chilean resistance movement. The award of the Prix Médicis, and Cortázar's donation of it, increased his already considerable visibility.

(Standish 2001: 132-33)

In a 1974 debate in the Argentine magazine La Opinión, Osvaldo Tcherkaski, a reporter for France-Presse, claimed that Cortázar's donation of the prize money 
to the Chilean resistance was evidence of France's fashionable interest in Latin American guerrilla movements and revolutions. Cortázar's friendship with Chile's ousted president, Salvador Allende, was also noted (Standish 2001: xvi, 12, 132-36). The intense debate was later continued in a special issue of La Opinión, with contributions from a variety of Latin American writers. There certainly could have been some political interest behind the prize, also given the previous reception of the work, which was mostly mixed.

In Argentina itself, Cortázar had many critics who wanted to deny him the right to an Argentine literary prize on the grounds that someone who had left his fatherland was not entitled to such an honor. The short story collection Alguien que anda por ahí (1977) was censored by the Perón government and did not appear in its entirety, because the story "Segunda Vez" referred to the disappeared in Argentina. Instead, the entire volume appeared, once again, in Mexico (Standish 1997: 467-68).

In summary, we can say that the political dimension certainly drew a lot of attention, and to some degree promoted the reception of Cortázar's work (for instance the reception of Libro de Manuel in France after the prize was awarded), but that to an even much greater degree, it apparently stood in the way of an appropriate recognition, for instance with respect to internationally recognized literary awards. Of course, there were other writers who also supported the revolutionary movements in Latin America or rejected the dictatorships of the Southern Cone and yet, at the same time, received important literary prizes. In his appraisal following Cortázar's death, Benedetti confirmed some of the dynamics that Cortázar had already addressed in his letters:

It is true that other Latin American writers, who took political stances similar to Cortázar's, have been favored with important prizes, but there were several things for which he was not forgiven: first, for having started as a writer in a literary context (specifically, that of the magazine Sur from Buenos Aires) that was frankly conservative, even reactionary, but then later taking such definitely leftist positions; and then, being a writer of fantastical topics (magic, fantasy, and dreams often serve as a way to escape from compromising reality today), for linking himself so closely to very concrete grievances of the real world, to so many anguishes of poor America. ${ }^{164}$

(Benedetti 2014: 272)

164 "Es cierto que otros autores latinoamericanos, políticamente afines a Cortázar, han sido favorecidos con importantes recompensas, pero a él no se le perdonaban varias cosas: por lo pronto que, habiéndose iniciado como escritor en un marco literario (concretamente, el de la revista Sur, de Buenos Aires), francamente conservador y hasta reaccionario, asumiera luego tan definidas posiciones de izquierda, y también que, siendo un escritor de temas fantásticos (la magia, la fantasía, los sueños sirven hoy frecuentemente para escabullirse de la comprometedora realidad), se vinculara tan estrechamente a muy concretas reivindicaciones del mundo real, a tantas angustias de la América pobre.” 
The Argentine writer Ricardo Piglia (2014) refers to another important point, namely the view that Cortázar is a better short story writer than he is a novelist an opinion that apparently established itself among many of Cortázar's readers after his death. We should recall at this point what was already mentioned earlier, namely that Aurora Bernárdez had already talked about the forty-year-olds who still expected short stories from Cortázar during his lifetime, while Rayuela was enjoying success with a very young audience. Piglia does point to the strong connections linking short stories and novels - cuentos and novelas - as well as the fact that Cortázar is very strongly rooted in the tradition of the Argentine novel (including Macedonio Fernández, Leopoldo Marechal, Roberto Arlt, and Adolfo Bioy Casares). But in addition, he describes Cortázar's poetics, in the novels, as "a poetics of risk, a poetics of rupture" (una poética del riesgo, una poética de la ruptura), explaining:

It seems to me that the opinion that Cortázar the short story writer is better than Cortázar the novelist tends to take that which is most conventional in Cortázar, not because Cortázar is not an extraordinary short story writer but because in his production as a writer of short stories he is closer to what we could call a kind of writing that meets the requirements of what could be considered a literature that responds to certain types of categories, that can be understood as literary common sense. Whereas Cortázar the novelist is basically the one who works with experimentation, rupture, schism, and who always goes a little beyond the ordinary. ${ }^{165}$

Piglia emphasizes that these breaches of convention can of course also become conventionalized forms themselves, over time, but that it is important to recognize Cortázar's achievement in this context: "What I am saying is that Cortázar should be valued for this position, which always tended to put him in danger, in situations that were not safe from the point of view of what he had achieved as a writer, and that this poetics is more visible, more fully present in his novels than in his short stories" (Estoy diciendo que Cortázar debe ser valorado por esa posición que tendía a ponerlo siempre en peligro, en situaciones no seguras desde

165 “me parece que la opinión que es mejor el Cortázar cuentista que el Cortázar novelista tiende a tomar de Cortázar lo más convencional, no porque Cortázar no sea un extraordinario cuentista sino porque, en su producción, como narrador de cuentos está más próximo a lo que podríamos llamar una escritura que cumple con los requisitos de lo que puede considerarse una literatura que responde a ciertos tipos de categorías, que pueden entenderse como el sentido común literario. Mientras que el Cortázar novelista es el que básicamente trabaja la experimentación, la ruptura, el corte y que va siempre un poco más allá de lo que se puede considerar que es el lugar común." 
el punto de vista de lo que él había conseguido como escritor, y que esta poética es más visible, es más plena en sus novelas que en sus cuentos; ibid.). Julio Cortázar's literary achievement, we could say in conclusion, in agreement with Piglia, can be seen precisely in the places where he is least accessible, which would seem to make a critical look at the processes of circulation all the more necessary in his case. 